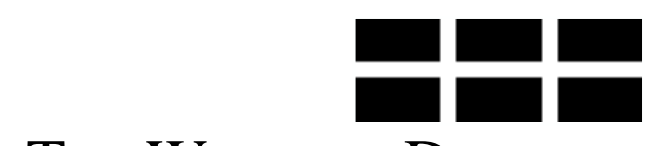

THE W ILLIAM DAVIDSON INSTITUTE AT THE UNIVERSITY OF MICHIGAN BUSINESS SCHOOL

\title{
Labor Force Participation Dynamics in the Romanian Labor Market
}

\author{
By: Alexandru Voicu
}

William Davidson Working Paper Number 481

July 2002 


\title{
Labor Force Participation Dynamics in the Romanian Labor Market
}

\author{
Alexandru Voicu \\ IZA, Bonn, Germany \\ email: voicu@iza.org
}

July 4, 2002

\begin{abstract}
We use micro data from the Romanian Labor Force Survey to analyze the effect of the restructuring process on the Romanian labor market. We identify the reallocation mechanisms at work in the Romanian labor market, and we analyze the way personal characteristics influence individuals' ability to adjust to labor market transformations. Special attention is given to the effect the emergence of the agricultural sector had on labor market transformations. Participation decisions made by individuals are modeled as Markov decision processes. The resulting multivariate probit models are estimated using Markov Chain Monte Carlo techniques.
\end{abstract}

Key words: labor force participation, transition economy, Markov chain Monte Carlo.

JEL classification: C15, C35, J23

\section{Introduction}

The study of labor market performance in transition economies has received a great deal of attention in the economic literature of recent years. An important component of the process of transition to a market economy, experienced by Central and East-European countries, is the emergence of labor markets. The restructuring process has involved a massive reallocation of labor under the influence of changes in productivity, demand shocks and changes in the the incentive structure. With very few exceptions, the countries in the region have experienced a sharp increase in unemployment. The rates of long-term unemployment have increased dramatically and many long-term job seekers have left the market. The uneven incidence of unemployment across country regions as well as across socio-economic and demographic groups has widened existing labor market imbalances. Numerous studies document the changes in labor markets since the beginning of transition. Barr (1994), Boeri (1994), Commander and Coricelli (1995), Commander and Tolstopiatenko (1997) use macro data 
to provide accounts of the evolution of employment, unemployment, and labor markets and the evolution of related social policies.

Through the effect on labor markets, the economic restructuring process has placed a heavy burden on social support systems and the labor market adjustment process. The reduction of employment and the increase in unemployment has increased the social security burden placing it on an ever shrinking part of the working population. Disparities in unemployment incidence lead to permanent reductions in the effective labor supply by discouraging the long-term unemployed, which may, in turn, lead to a further widening of the existing disparities. This long-term phenomenon has two main effects. First, it increases the pressure on the social support systems and, second, regional imbalances in the incidence of unemployment may mobilize communities against further reductions in employment, thereby delaying the restructuring process in high unemployment areas. Therefore, identifying the trends in labor market evolutions as well as the disequilibria affecting labor market adjustments is important in designing an effective social safety net and active labor market policies aimed at facilitating the restructuring process.

The study of individual labor force histories provides an important insight on the effect of privatization and restructuring on the labor markets. Generally, such studies measure the effects of personal characteristics, labor market conditions, and active labor market policies on individuals' labor market experience. The results lead to the identification of imbalances across socio-economic groups and locations. Secondly, the restructuring process cannot be construed as and equilibrium process. It is very likely that the number of factors influencing the process as well as the magnitude of their respective effects change over time. Studies of individual labor force histories, using flexible frameworks, can provide an accurate description of this process.

A fast growing body of literature uses the study of individual labor force histories to document the evolution in the Central and East European labor markets in the period following the fall of the communist regimes. A comprehensive review of this literature is provided in Svejnar (1999). From an econometric point of view, most of the papers analyzing individual labor market histories can be classified in two broad categories: a) studies that use duration models and b) studies that model individuals' transitions among the labor force states as a Markov chain process. Most of the studies in the first category estimate the duration of unemployment as a function of personal characteristics and labor market conditions. The micro data sets used are suitable to the estimation of hazard functions, have a relatively small number of observations and, generally, are not publicly available. In this category, the most relevant examples are Ham et al. (1998), Ham et al. (1999), Finta and Terrel (1997), Abraham and Vodopivec (1993), Micklewright and Nagy (1995,1997), and Earle and Pauna (1998). The results vary in significance but they all find that age and higher education have a positive effects on the probability of exiting unemployment. Vocational training or, more generally, a high level of firm and industry specific skills is found to improve the chances of finding a job by Ham et al. (1998) and Ham et al. (1999) while Earle and Pauna (1998) find a weak negative effect of 
specific skills on the probability of exiting unemployment.

The studies in the second category model individuals' experiences as a Markov chain process. The Markov chain process is characterized by a transition matrix. The probabilities that form the transition matrix are parametrized as function of individuals' characteristics and labor market conditions. Certain dimensions of the transition matrix are then estimated, generally using multinomial logit models. The data sets used are large panels constructed from labor force survey data. Again, the effects of personal characteristics on the individuals' labor force histories vary widely in significance and sign. Age is found to have a weak positive effect of the probability of exiting unemployment by Storm and Terrell (1997). Using categorical definition of age, Bellmann et al. (1995) and Earle(1997) find that older individuals have a lower probability of finding a job and a higher probability of dropping out of the labor force. Jones and Kato (1997) find higher education and experience increase women's chances of finding jobs.

All the studies mentioned above share one important feature which has been rarely, if ever, mentioned. The economic transition provides the perfect empirical framework for studying the effect of education and type of skills on workers' mobility and ability to adapt to changing labor market conditions. It is widely accepted that educational choice is endogenous to the labor supply decision. Thus, under normal conditions, the study of labor supply as a function of educational attainment is likely to be affected by endogeneity bias. In a transition economy setting, however, most individuals made the education decisions prior to the beginning of transition, and, the overwhelming majority, without expecting any major change. As a result, the sudden changes in labor markets brought about by the transition process provide a natural experiment for labor supply studies.

The studies in the second category, to which the present paper is related, have two major drawbacks. First, all of them use panels no longer then two periods, even when longer panels are available. Secondly, to our knowledge, none of the study estimates the full model. The Markov chain model of individual histories requires that the individual's contributions to the likelihood function describes the individual's full history (the product of the probability occupying the initial state and the transition probabilities corresponding to the individual's history) (Amemya, 1985). The papers we review in this section use a different approach. First, the sample is divided in subsamples corresponding to initial states. Then the estimation is carried out separately for each sub sample generally using multinomial logit models. This approach precludes any meaningful comparison across sub samples of the effects of independent variables on transition probabilities. Moreover, selection bias is likely to affect the results since the sub-sample used is selected based on the value of the dependent variable in the previous period.

In this paper we use micro data from the Romanian Labor Force Survey to analyze the effect of privatization on the Romanian labor market. We document the uneven incidence of unemployment in general and long term unemployment in particular across several dimensions - age, gender, education and rural/urban 
location. First, we estimate a two state model of labor force participation. As the results indicate that agriculture plays an important role, we employ a threestate model to investigate the effect of the emergence of the agricultural sector on the labor markets. The estimation method used overcomes the problems common to dynamic participation models. Participation decisions made by individuals are modeled as Markov decision processes. The resulting multivariate probit models are estimated using Markov Chain Monte Carlo methods introduced by Chib and Greenberg (1998). The method allows a high degree of flexibility in the construction of the model and in specifying the correlation matrix for the multivariate probit model. It also avoids the convergence problems that hamper the maximum likelihood estimation.

The remainder of the paper is organized as follows. The next section contains a short description of the economic restructuring process in Romania. In section three we present the data set. The empirical specification and the estimation results for the two state model are presented in section four followed by results from a reduced study of the three-state model.

\section{Economic Restructuring in Romania}

Four important components of the restructuring process affected the labor markets in the period to which this study refers:

1. Privatization of the state sector.

2. Restructuring of the remaining state owned enterprises aimed at increasing their productivity.

3. Creation of a new private sector.

4. The emergence of the private agricultural sector follwing land reform legislation.

Compared to the more advanced transition economies, in Romania, the restructuring process took place at a slow pace in the early 1990s. In spite of the slow pace at which they proceeded, the privatization and restructuring of the state sector, and the emergence of the new private sector had a strong effect on the labor market. In non-agricultural sectors, approximately 1,241,000 jobs (approx. 25 percent of the total) were lost between 1992 and 1996 most of them in large firms in manufacturing sectors, transportation, extraction of crude oil and construction. In the same period only slightly more than 700,000 new jobs were created mainly in small firms. The sectors the fared best in job creation were manufacturing of wood products, trade, utilities, services. This pattern of job creation and destruction indicates the presence an intense process of intersectoral reallocation of labor. Earle (1997) provides a detailed study of labor reallocation among industrial sectors.

The net effect of the process was the reduction of the number of jobs by more than 10 percent between 1992 and 1996. Yet, in the same period both the labor force participation and the unemployment rate remained remarkably stable. The participation rate hovered around 73 percent and registered unemployment, after reaching 11 percent in 1994, fell to about 7 percent in 1996. This somehow 
puzzling situation may be due the sharp increase in employment in agricultural sector.

The private agricultural sector emerged following the 1991 land reform legislation. The study of this piece of legislation and of the resulting institutional settings are very interesting in their own right. For the purpose of this paper, however, we shall limit ourselves to two aspects: the sources of the sharp increase in the size of this sector, and the quality of employment in agriculture. Following the 1991 land reform legislation, the private agricultural sector became the destination of important flows across labor force states. Many people who were not in the labor force started reporting a normal number of hours of work after the redistribution of land. This increased both labor force participation and employment. On the other hand, some of the people who owned land in rural areas and, at the same time, held jobs in industrial firms had been laid-off during the restructuring process. As land owners, they were not entitled to unemployment benefits and started reporting normal number of hours in the agricultural sector. While being officially considered employed, they are rather under-employed, most of them seeking jobs outside agriculture. The vast majority of people employed in the private agricultural sector are self-employed, which means that their present labor force status was determined by land ownership and that they were a part of this double-sided reallocation process. The highly fragmented ownership pattern and the lack of capital had a negative effect on the productivity of small farms, making farming largely a subsistence activity. Moreover, the lack of social benefits as well as of any institution aimed at protecting farmers makes jobs in this sector of much lower quality than in any other sector. The large employment share of agriculture (roughly one third of total employment) underscores the relevance of its emergenge to the study of labor market transformations.

The presence of a mass reallocation of labor among industrial sectors as well as the large inflow of workers from industrial sectors and non-participants in the labor force into the agricultural sector motivates this study. We study the way personal characteristics affect individuals' labor market experiences in the course of this process.

\section{Data}

We draw our data from the Romanian Labor Force Survey, conducted in March 1994 and March 1995. The questionnaire was administered on a representative sample of Romanian households, selected on the basis the population census conducted in January 1992. This survey contains standard labor force participation and unemployment questions about the current status of the respondent. For the purpose of analyzing labor market transitions, it also has two important features. First, the survey contains retrospective questions about the labor market activity of the respondent the year prior to the survey. Thus, we are able to use the 1993 labor market status of the participants in the 1994 survey. The other feature is that nearly all of the respondents in 1994 were re-interviewed in 


\section{William Davidson Institute Working Paper 481}

the 1995 survey. With some effort, it is possible to match unambiguously nearly all the cases. Thus, we were able to construct a three-period panel with 22835 observations, including the retrospective information on labor market activity in 1993.

Among the variables in the dat set, education deserves special attention. Educational levels as described in the survey differ not only in terms of years of schooling necessary to attain a certain level but also in terms of industry specific, firm specifics, and managerial skills.

The level of education is described by the following seven categories: primary school, gymnasium, vocational, high school, foreman, post-high-school training (in presenting the results, I refer to this category as HIPLUS), and university. In the Romanian educational system primary school represents the first four years of education. The gymnasium consists of the next four years. After completing the first eight years, a gymnasium graduate may choose either to go to high school or vocational school. The vocational schools are usually run by big industrial firms or co-op associations and provide students with a high level of specific skills. The degree of specificity varies from firm-specific to branch- or sector-specific. Usually, it takes two years to complete vocational school, and at graduation such students are offered a job by the firm that runs the school. Unlike vocational schools, highschool provides students only with general skills. After completing the high school, one may choose either to go to a university or to enter the labor market. There are also two other forms of formal training distinguished in this survey. The post-high school training can be pursued by the high school graduates and provides students with branch specific skills. Foreman schools provide both technical (branch specific) and managerial training. Firms enroll their employees in the foreman schools and pay all the expenses.

We recognize two important problems in the way we constructed the panel data set. First, to construct the panel we used retrospective reports of the labor force status in 1993. It is generally recognized (Bound et al. 1990) that constructing labor force history from retrospective information involves a potential for measurement error. Secondly, it is most likely that the sample loss, which occurred between the surveys, is not random. Therefore, the estimates based on the selected sample may be biased. While, at present, we have no good way to deal with the first problem, the nonrandom sample loss will be addressed in further research.

The sample composition by individual characteristics used in this study is presented in table 1 . In table 2 , we report sample distribution over labor market states for years 1993 to 1995 . In the reaminder of this paper, for the study of employment dynamics, we aggregate unemployed and nonparticipants in the labor force into one category - nonworking. 
Table 1. Sample composition

\begin{tabular}{|c|c|c|c|}
\hline TOTAL & \multicolumn{3}{|c|}{22835} \\
\hline Gender & Female & Male & Total \\
\hline & 11001 & 11834 & 22835 \\
\hline Education & Female & Male & Total \\
\hline Primary & $1630(14.81 \%)$ & $1344(11.36 \%)$ & 2974 \\
\hline Gymnasium & $3692(33.56 \%)$ & $3065(25.90 \%)$ & 6757 \\
\hline Vocational & $1446(13.14 \%)$ & $3483(29.43 \%)$ & 4929 \\
\hline High-school & $3078(27.97 \%)$ & $2223(18.78 \%)$ & 5301 \\
\hline Foreman & $55(0.49 \%)$ & $532(4.50 \%)$ & 587 \\
\hline HIPLUS & $438(3.98 \%)$ & $276(2.33 \%)$ & 714 \\
\hline University & $662(6.01 \%)$ & $911(7.70 \%)$ & 1573 \\
\hline Rural/urban location & Female & Male & Total \\
\hline Rural & $4661(42.36 \%)$ & $5580(47.15 \%)$ & 10241 \\
\hline Urban & $6340(57.63 \%)$ & $6254(52.84 \%)$ & 12594 \\
\hline Age & Female & Male & Total \\
\hline Mean & 36.31 & 37.79 & 37.08 \\
\hline
\end{tabular}

Overall employment increased over the two-year period from 1993 to 1995. This was mainly due to a significant increase in the size of the private agricultural sector, which offsets the decline of the state sector. The employment in the emerging private non-agricultural sector nearly doubled during the same period. At the same time, labor force participation slightly increased.

Table2. Sample composition by labor force status.

\begin{tabular}{||l|c|c|c||}
\hline \hline Labor force status & $\mathbf{1 9 9 3}$ & $\mathbf{1 9 9 4}$ & $\mathbf{1 9 9 5}$ \\
\hline Employed & $15445(67.63 \%)$ & $15826(69.30 \%)$ & $16326(71.49 \%)$ \\
State & $10412(45.59 \%)$ & $9892(43.31 \%)$ & $9300(40.72 \%)$ \\
Private agr. & $3377(14.78 \%)$ & $4068(17.81 \%)$ & $4642(20.24 \%)$ \\
Private non-agr. & $1084(4.74 \%)$ & $1368(5.99 \%)$ & $1837(8.04 \%)$ \\
Other & $572(2.50 \%)$ & $498(2.18 \%)$ & $565(2.47 \%)$ \\
Not employed & $7390(32.36 \%)$ & $7009(30.69 \%)$ & $6509(28.50 \%)$ \\
Unemployed & $1798(7.78 \%)$ & $1516(6.63 \%)$ & $1479(6.47 \%)$ \\
Non-participants & $5592(24.48 \%)$ & $5493(24.05 \%)$ & $5030(22.02 \%)$ \\
Labor force participants & $17243(75.51 \%)$ & $17342(75.94 \%)$ & $17805(77.97 \%)$ \\
Total & 22835 & 22835 & 22835 \\
\hline \hline
\end{tabular}

Using the same definition of the labor market states, we constructed transition matrices for 1993-1994 and 1994-1995. The transition matrices, presented in Tables A.1-A.3 in the Appendix A, show that the private agricultural sector represents an important destination for the transitions in the labor market. Not only did a large proportion of individuals leaving the state sector enter the private agricultural sector, but also many previously nonworking individuals became employed in this sector by receiving land. 


\section{A two-state model of labor force participation}

\subsection{Empirical specification}

In this paper we study the labor force participation dynamics in an economy undergoing an extensive privatization process. Studies of labor force supply have been categorized by Heckman (1993) in labor supply choices at the extensive margin (labor force participation and employment choices) and choices at the intensive margin (choices about hours of work or weeks of work for workers). This study falls into the first category, as we are interested in decision to participate or be employed and not in the number of hours worked.

The empirical specification employed is consistent with the results of search models, which are often used in dynamic labor supply studies (for example, Hyslop, 1999). Each period individuals receive one wage offer from the known distribution of wages. Denote the distribution of wages by $F\left(w ; \mu, \sigma_{1}^{2}\right)$ where $\mu$ and $\sigma_{1}^{2}$ are the mean and the variance of the distribution. We assume that the conditional mean is a linear function of personal characteristics and that the variance does not depend on the personal characteristics. Denote the distribution of wages, conditional on personal characteristics by $F_{\mid X}\left(w ; X_{1} \beta, \sigma_{1}^{2}\right)$. The wage offer can then be represented as

$$
W=X_{1} \beta+\epsilon_{1}, \epsilon_{1} \sim\left(0, \sigma_{1}^{2}\right)
$$

The wage offer is compared with the individual's reservation wage. In the setting of search models, the reservation wage is the result of a dynamic optimization problem. For a given individual, the reservation wage is deterministic since it is a function of the known parameters of the dynamic optimization problem. The reservation wage, however is not observed by the econometrician. From the econometrician's perspective reservation wage is a random variable that depends on personal characteristics in the following manner:

$$
W^{*}=X_{1} \gamma+X_{2} \delta+\epsilon_{2}
$$

where $X_{1}$ is the set of personal characteristics which determine the mean of the wage offer, $X_{2}$ is a set of personal characteristics that influence the reservation wage only and $\epsilon_{2}$ are i.i.d. $\left(0, \sigma_{2}^{2}\right)$.

We further assume that personal characteristics are time invariant. We assume, however, that their effects on the wage and reservation wage change with time. This assumption allows for possible changes in the wage offer distribution facing an individual and for a variable reservation wage. Under these assumptions, the wage and reservation wage become, respectively,

$$
\begin{aligned}
& w_{i t}=X_{1 i} \beta_{t}+\epsilon_{1 i t} \\
& w_{i t}^{*}=X_{1 i} \gamma_{t}+X_{2 i} \delta_{t}+\epsilon_{2 i t}
\end{aligned}
$$




\section{William Davidson Institute Working Paper 481}

The reduced-form specification of the dynamic employment decision becomes

$$
h_{i t}=I\left(w_{i t}-w_{i t}^{*}>0\right)
$$

or,

$$
h_{i t}=I\left(X_{1 i}\left(\beta_{t}-\gamma_{t}\right)-X_{2 i} \delta_{t}+\epsilon_{1 i t}-\epsilon_{2 i t}>0\right)
$$

Denote $\bar{X}=\left[X_{1} \mid X_{2}\right], \bar{\beta}_{t}=\left[\begin{array}{c}\beta_{t}-\gamma_{t} \\ \delta_{t}\end{array}\right]$ and $u_{i t}=\epsilon_{1 i t}-\epsilon_{2 i t}$. It follows:

$$
h_{i t}=I\left(\bar{X}_{i} \bar{\beta}_{t}+u_{i t}>0\right)
$$

where $u_{i t}$ is assumed to be normally distributed, $E\left[u_{i t}\right]=0, u_{i t}$ are independent over $i$ 's and to have a correlation structure over $t$ given be the following correlation matrix:

$$
\Sigma=\left[\begin{array}{ccccc}
1 & \sigma_{12} & \sigma_{13} & \ldots . & \sigma_{1 T} \\
\sigma_{21} & 1 & \sigma_{23} & \ldots . & \sigma_{2 T} \\
\sigma_{32} & \sigma_{32} & 1 & \ldots . & \sigma_{3 T} \\
\cdot & \cdot & \cdot & \ldots . & \cdot \\
\cdot & \cdot & \cdot & \ldots . & \cdot \\
\sigma_{T 1} & \sigma_{T 2} & \sigma_{T 3} & \ldots & \sigma_{T T}
\end{array}\right]
$$

where $t=1 \ldots T$.

Under these assumptions, the dynamic employment decision model becomes a multivariate probit model. We estimate this model using Markov Chain Monte Carlo methods.

\subsection{Estimation Results}

We estimate the dynamic participation model using a three-period panel. The reduced specification, derived in the presious section is given by:

$$
y_{i t}=I\left(X_{i} \beta_{t}+u_{i t}>0\right) i=1 \ldots N, t=1 \ldots T
$$

where $T=3, u_{i t}$ is normally distributed, $E\left[u_{i t}\right]=0, u_{i t}$ are independent over $i$ 's and it has a correlation structure over $t$ given by:

$$
\Sigma=\left[\begin{array}{ccc}
1 & \sigma_{12} & \sigma_{13} \\
\sigma_{21} & 1 & \sigma_{23} \\
\sigma_{32} & \sigma_{32} & 1
\end{array}\right]
$$




\section{William Davidson Institute Working Paper 481}

The binary dependent variable $y_{i t}=1$ if individual $i$ works at time $t$ and $y_{i t}=0$ otherwise. $X_{i}$ is a vector of time invariant personal characteristics that affect the individual's participation decision and $\beta_{t}$ are time variant coefficients. Thus, we allow the effect of personal characteristics on employment decision to vary over time. The components of $X$ are: rural/urban location, gender, age, and education - a categorical variable with seven categories.

The model defined this way is a multivariate probit model. We estimate it using the MCMC algorithm introduced by Chib and Greenberg (1998). Appendix B gives a description of the algorithm. For a detailed description, see Voicu (2001). The estimation involves introducing the latent variable $Z_{i t}$. The latent variable represents, in this case, the difference between the wage offer and the reservation wage.

$$
\begin{aligned}
Z_{i t} & =X_{i} \beta_{t}+u_{i t} \\
y_{i t} & =I\left(Z_{i t}>0\right)
\end{aligned}
$$

In the Bayesian paradigm, the goal is to find the posterior distribution of the parameters. In general, this is done by integrating out the nuisance parameters from the joint posterior distribution. The moments of the posterior distribution and the high posterior density estimates are the equivalent of sample estimates and confidence intervals calculated in the frequentist paradigm. We estimate the three sets of $\beta$ as well as the components of the correlation matrix $\sigma_{12}, \sigma_{13}$ and $\sigma_{23}$. Table 3 reports the posterior means, the posterior standard deviation (PSTD), and the numerical standard errors (NSE) for the $\beta s$. The numerical standard errors were calculated using spectral density methods (Geweke, 1992). The interpretation of the $\beta$ is the same as that in linear regression with dependent variable $Z_{i t}$.

Results indicate that living in urban areas has a negative effect on the probability of being employed. Older people are more likely to be employed. Men fare better than women. More education and firm/industry-specific skills improved an individual's likelihood of being employed. Over time, the negative effect of urban residence increased in absolute value, the gap between men and women widened, whereas the effect of age became smaller. University educated workers continue to have the brightest employment prospects. While firm- and industryspecific skills continue to be an important factor, their effect on the probability of being employed diminished relative to general skills and high level of education. The posterior moments for the correlation coefficients are presented in Table 4. The first thing to note is the high correlation of the three error terms. From a technical point of view, this validates the choice of a multivariate probit model for this application. Imposing restrictions on the form of the correlation matrix (for example estimating the model as an independent probit model) would have led to incorrect inferences. The high positive correlation coefficients indicates that unobserved heterogeneity and state dependence influence individuals' work histories. 
William Davidson Institute Working Paper 481

Table 3. Moments of the posterior distribution for the coefficients.

\begin{tabular}{||l|l|l|l||}
\hline \hline Variable & \multicolumn{3}{|c||}{1993} \\
\cline { 2 - 4 } Const. & mean & PSTD & NSE \\
\cline { 2 - 4 } Urban & -1.055 & 0.0461 & 0.00073 \\
Gender & -0.321 & 0.0203 & 0.00035 \\
Age & 0.141 & 0.0192 & 0.00031 \\
Gymnasium & 0.029 & 0.0008 & $1.27 \mathrm{E}-05$ \\
Vocational & 0.890 & 0.0318 & 0.00047 \\
Foreman & 0.813 & 0.0693 & 0.00056 \\
High school & 0.750 & 0.0354 & 0.00122 \\
HIPLUS & 1.153 & 0.0659 & 0.00130 \\
University & 1.310 & 0.0517 & 0.00103 \\
\hline \hline \hline Variable & \multicolumn{3}{|c||}{1994} \\
\cline { 2 - 4 } Const. & mean & PSTD & NSE \\
\cline { 2 - 4 } & -0.457 & 0.0463 & 0.00074 \\
Urban & -0.514 & 0.0205 & 0.00034 \\
Gender & 0.239 & 0.0194 & 0.00031 \\
Age & 0.019 & 0.0008 & $1.31 \mathrm{E}-05$ \\
Gymnasium & 0.137 & 0.0322 & 0.00051 \\
Vocational & 0.732 & 0.0359 & 0.00058 \\
Foreman & 0.762 & 0.0695 & 0.00123 \\
High school & 0.661 & 0.0359 & 0.00059 \\
HIPLUS & 1.120 & 0.0666 & 0.00130 \\
University & 1.324 & 0.0535 & 0.00117 \\
\hline \hline Variable & \multicolumn{3}{|c||}{1995} \\
\cline { 2 - 4 } Const. & mean & PSTD & NSE \\
\cline { 2 - 4 } Urban & 0.037 & 0.0461 & 0.00074 \\
Gender & -0.612 & 0.0205 & 0.00032 \\
Age & 0.236 & 0.0193 & 0.00032 \\
Gymnasium & 0.010 & 0.0008 & $1.22 \mathrm{E}-0.5$ \\
Vocational & 0.090 & 0.0322 & 0.00052 \\
Foreman & 0.667 & 0.0361 & 0.00060 \\
High school & 0.579 & 0.0689 & 0.00118 \\
\hline \hline
\end{tabular}


Table 4. Moments of the posterior distribution for correlation coefficients.

\begin{tabular}{|c|c|c|c|c|c|c|c|}
\hline \multirow[b]{3}{*}{ work93 } & work93 & \multicolumn{3}{|c|}{ work94 } & \multicolumn{3}{|c|}{ work95 } \\
\hline & mean std. & mean & pop. std. & NSE & mean & pop. std. & NSE \\
\hline & 1 & 0.518 & 0.0056 & 0.00011 & 0.461 & 0.0062 & 0.00014 \\
\hline work94 & & & 1 & & 0.482 & 0.0061 & 0.00013 \\
\hline work95 & & & & & & 1 & \\
\hline
\end{tabular}

It is important to note that the $\beta$ measure the effects of personal characteristics on the latent variables. Individuals' participation decisions depend, however, on the latent variables crossing a certain treshold (0 in our case) and labor market histories are sequences of participation decisions. To completely describe the effect of personal characteristics on individuals' experiences, we calculate their effect on the probabilities of three types of events:

1. Probability of being employed in each of the three years of the panel.

2. Probability of transition between participation and non-participation.

3. Probability that individuals experience complete paths (for example they are employed in all three years).

The probabilities are calculated for 28 categories of individuals who differ with respect to their gender, location and education. In a three-period two-state model, there are eight possible histories. The probability of a complete history is the cumulative distribution function (CDF) of a trivariate normal distribution. To calculate the normal CDFs, we use the GHK smooth recursive simulator (Geweke,1989; Hajivassiliou,1990; and Keane, 1994. Greene, 1997). For all categories, the probabilities corresponding to the eight possible histories are evaluated at each Gibbs sampler step. The posterior means are then reported. The employment probabilities and the transition probabilities are calculated by adding the probabilities of the relevant histories.

\subsubsection{Employment Probabilities}

Three main stories emerge from the results in table 5. Urban/rural location has two main effects. Rural residents have higher probabilities of being employed regardless of gender and level of education. Secondly, the dynamic of employment probability across locations is very different. Urban residents experience small changes in employment probabilities with signs varying across gender and education, while the rural residents saw their employment probabilities increased by a significant margin. These two effects may be the result of the significant increase in employment in agriculture.

The second story is the sharp difference between men and women. Men have a higher probability of being employed in all three years, for all levels of educational attainment and regardless of location. The dynamic of employment probabilities also favors men. For all categories of education and locations, men 


\section{William Davidson Institute Working Paper 481}

experienced either larger increases or smaller reductions in the employment probability over time.

Finally, with respect to education, we note that better-educated individuals and individuals with specific skills have a higher employment probabilities. The most interesting aspect is the comparison specific versus general skills (vocational and foreman vs. highschool groups). Vocational training is associated with the highest employment probabilities in 1993. From then on, however, this group experienced the least favorable trend of the three groups, for men and women, and urban an rural location (for the latter, this trend is likely entangled with the increase in agricultural employment). This change may be regarded as evidence, albeit weak, of the reduced mobility of individuals with specific skills.

Table 5. Employment probabilities

\begin{tabular}{|c|c|c|c|c|}
\hline \multicolumn{2}{|l|}{ Category } & 1993 & 1994 & 1995 \\
\hline \multirow[t]{7}{*}{ Urban/Male } & Primary & 0.441 & 0.485 & 0.515 \\
\hline & Gymnasium & 0.544 & 0.540 & 0.551 \\
\hline & Vocational & 0.771 & 0.756 & 0.759 \\
\hline & Foreman & 0.746 & 0.765 & 0.768 \\
\hline & High school & 0.726 & 0.733 & 0.731 \\
\hline & HIPLUS & 0.842 & 0.860 & 0.862 \\
\hline & University & 0.877 & 0.900 & 0.896 \\
\hline \multirow[t]{7}{*}{ Urban/Female } & Primary & 0.386 & 0.391 & 0.421 \\
\hline & Gymnasium & 0.488 & 0.444 & 0.457 \\
\hline & Vocational & 0.726 & 0.675 & 0.680 \\
\hline & Foreman & 0.699 & 0.686 & 0.691 \\
\hline & High school & 0.677 & 0.649 & 0.648 \\
\hline & HIPLUS & 0.806 & 0.800 & 0.804 \\
\hline & University & 0.846 & 0.852 & 0.847 \\
\hline \multirow[t]{7}{*}{ Rural/Male } & Primary & 0.569 & 0.683 & 0.742 \\
\hline & Gymnasium & 0.667 & 0.730 & 0.770 \\
\hline & Vocational & 0.856 & 0.886 & 0.906 \\
\hline & Foreman & 0.837 & 0.892 & 0.910 \\
\hline & High school & 0.822 & 0.872 & 0.890 \\
\hline & HIPLUS & 0.907 & 0.944 & 0.956 \\
\hline & University & 0.931 & 0.964 & 0.969 \\
\hline \multirow[t]{7}{*}{ Rural/Female } & $\overline{\text { Primary }}$ & 0.513 & 0.593 & 0.660 \\
\hline & Gymnasium & 0.615 & 0.646 & 0.693 \\
\hline & Vocational & 0.822 & 0.833 & 0.860 \\
\hline & Foreman & 0.800 & 0.841 & 0.866 \\
\hline & High school & 0.783 & 0.815 & 0.839 \\
\hline & HIPLUS & 0.881 & 0.912 & 0.929 \\
\hline & University & 0.910 & 0.940 & 0.949 \\
\hline
\end{tabular}




\subsubsection{Transition Probabilities}

To analyze the dynamic patterns in employment, we estimate probabilities of transition between participation and non-participation. Table 6 presents the estimated transition probabilities for 1993-1995 by education, gender and rural $\backslash$ urban location. The four columns are: the probability of staying employed (E-E), probability of losing the job (E-NE), probability of finding a new job when unemployed (NE-E) and the probability of staying unemployed (NE$\mathrm{NE}$ ). The transition probabilities describe individuals' mobility (the likelihhood of experiencing many transitions across labor force states). For groups with high turnover rates, the net inflows into employment provide a basis for inference on long-term labor market prospects.

We found that individuals leaving in rural areas have higher probabilities of remaining employed and lower probabilities of maintaining a non-working status. Their mobility is significantly lower than that of urban residents. The net effect of flows in and out of employment is positive for all categories of rural residents while it forms a mixed picture for urban residents. As we do not account for job-to-job transitions, these results can be explained by the emergence of the agricultural sector. Workers who lost their jobs in the non-agricultural sector and were reclassified as employed in the agricultural sector would artificially inflate the probabilities in the first column. A large part of the flows from nonemployment into employment, especially for low levels of education, may be made up by non-participants reclassified after land redistribution as employed in agriculture.

With no exception, women have lower probabilities of staying employed and higher probabilities of losing their jobs. The probabilities of finding new jobs are not very different for men and women living in urban areas (except those with low education). Among rural residents, women fare better in this respect, most probably due to the large inflows in agriculture. For urban residents, the net effects of inflows into employment are larger for men, for all categories of education. This result implies that, if this trend should continue, the gap between the job prospects of men and women will widen.

Higher education and specific skills improve the probability of maintaining employment, with specific skills being more valuable than general training. Individuals with higher levels of education have a lower mobility over labor force states. The net inflows into employment tell a very interesting story. Individuals with vocational training are the only category of men, urban residents, with negative net inflows. For women, this category has the largest negative net inflow. This result provides support to the hypothesis that while individuals with specific skills are less likely to lose their jobs in the first place, if unemployed they will have a harder time finding new jobs. In the long-run, they will experience high joblessness rates and most likely long non-working spells. 
William Davidson Institute Working Paper 481

Table 6. Transition probabilities, 1993-1995

\begin{tabular}{|c|c|c|c|c|c|}
\hline \multicolumn{2}{|l|}{ Category } & $\overline{\overline{E-E}}$ & 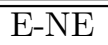 & NE-E & $\overline{\mathrm{NE}-\mathrm{NE}}$ \\
\hline \multirow[t]{7}{*}{ Urban/Male } & Primary & 0.302 & 0.139 & 0.213 & 0.346 \\
\hline & Gymnasium & 0.375 & 0.169 & 0.176 & 0.280 \\
\hline & Vocational & 0.635 & 0.136 & 0.124 & 0.105 \\
\hline & Foreman & 0.624 & 0.122 & 0.144 & 0.110 \\
\hline & High school & 0.587 & 0.139 & 0.144 & 0.130 \\
\hline & HIPLUS & 0.757 & 0.085 & 0.105 & 0.053 \\
\hline & University & 0.809 & 0.068 & 0.087 & 0.036 \\
\hline \multirow[t]{7}{*}{ Urban/Female } & Primary & 0.235 & 0.151 & 0.186 & 0.428 \\
\hline & Gymnasium & 0.299 & 0.190 & 0.158 & 0.354 \\
\hline & Vocational & 0.554 & 0.172 & 0.127 & 0.148 \\
\hline & Foreman & 0.544 & 0.155 & 0.146 & 0.154 \\
\hline & High school & 0.505 & 0.173 & 0.143 & 0.179 \\
\hline & HIPLUS & 0.689 & 0.116 & 0.115 & 0.080 \\
\hline & University & 0.749 & 0.097 & 0.098 & 0.056 \\
\hline \multirow[t]{7}{*}{ Rural/Male } & Primary & 0.483 & 0.085 & 0.258 & 0.173 \\
\hline & Gymnasium & 0.570 & 0.098 & 0.200 & 0.132 \\
\hline & Vocational & 0.799 & 0.057 & 0.107 & 0.037 \\
\hline & Foreman & 0.787 & 0.051 & 0.124 & 0.039 \\
\hline & High school & 0.760 & 0.062 & 0.130 & 0.048 \\
\hline & HIPLUS & 0.878 & 0.029 & 0.077 & 0.015 \\
\hline & University & 0.910 & 0.021 & 0.060 & 0.010 \\
\hline \multirow[t]{7}{*}{ Rural/Female } & Primary & 0.408 & 0.105 & 0.252 & 0.235 \\
\hline & Gymnasium & 0.492 & 0.123 & 0.201 & 0.184 \\
\hline & Vocational & 0.740 & 0.082 & 0.120 & 0.058 \\
\hline & Foreman & 0.727 & 0.073 & 0.139 & 0.061 \\
\hline & High school & 0.696 & 0.086 & 0.143 & 0.074 \\
\hline & HIPLUS & 0.836 & 0.045 & 0.092 & 0.026 \\
\hline & University & 0.876 & 0.034 & 0.073 & 0.017 \\
\hline
\end{tabular}




\subsubsection{Probabilities of entire paths}

Finally, we explore the effect of personal characteristics on the probability of individuals experiencing entire paths. There are 8 possible employment paths. For the same categories as before, in table 7 , we present the probability of participation in all three years and the probability of non-participation in all three years. Owing to the emergence of the agricultural sector, rural residents have higher employment probabilities and lower probabilities of not working in all three years. Higher education and a high level of specific skills increase the chance of being employed in all three years. The rates of long-term nonemployment are highest for less educated people (around 25 percent for men and 35 percent for women) and among high school graduates. Women have lower participation probabilities than men, for all education categories.

Table 7. Probabilities over entire paths

\begin{tabular}{|c|c|c|c|}
\hline \multicolumn{2}{|l|}{ Category } & Empl.93-95 & Not Empl.93-95 \\
\hline \multirow[t]{7}{*}{ Urban/Male } & Primary & 0.228 & 0.263 \\
\hline & Gymnasium & 0.289 & 0.207 \\
\hline & Vocational & 0.551 & 0.065 \\
\hline & Foreman & 0.548 & 0.066 \\
\hline & High school & 0.506 & 0.082 \\
\hline & HIPLUS & 0.698 & 0.028 \\
\hline & University & 0.763 & 0.017 \\
\hline \multirow[t]{7}{*}{ Urban/Female } & Primary & 0.163 & 0.346 \\
\hline & Gymnasium & 0.214 & 0.280 \\
\hline & Vocational & 0.456 & 0.101 \\
\hline & Foreman & 0.455 & 0.103 \\
\hline & High school & 0.413 & 0.124 \\
\hline & HIPLUS & 0.613 & 0.047 \\
\hline & University & 0.687 & 0.030 \\
\hline \multirow[t]{7}{*}{ Rural/Male } & Primary & 0.411 & 0.112 \\
\hline & Gymnasium & 0.493 & 0.083 \\
\hline & Vocational & 0.747 & 0.019 \\
\hline & Foreman & 0.739 & 0.019 \\
\hline & High school & 0.707 & 0.025 \\
\hline & HIPLUS & 0.849 & 0.006 \\
\hline & University & 0.889 & 0.003 \\
\hline \multirow[t]{7}{*}{ Rural/Female } & Primary & 0.328 & 0.166 \\
\hline & Gymnasium & 0.403 & 0.127 \\
\hline & Vocational & 0.670 & 0.033 \\
\hline & Foreman & 0.664 & 0.033 \\
\hline & High school & 0.627 & 0.042 \\
\hline & HIPLUS & 0.793 & 0.012 \\
\hline & University & 0.843 & 0.007 \\
\hline
\end{tabular}


Results of the two-state model of labor force participation are interesting in several respects. We found strong effects of personal characteristics on labor force histories. High positive correlation coefficients provide evidence of unobserved heterogeneity affecting the participation decision process. Older individuals are more likely to be employed. Higher education improves labor market prospects. Workers with vocational training have lower probabilities of losing their job. Once they become unemployed, however, they have a much harder time finding employment. Unlike other studies, we found a significant gap between the labor market prospects of men and women in favor of men. Comparing estimated employment probabilities, transition probabilities and probabilities over entire paths we found that men fare better than women in all respects. Regardless of location and level of education, men have higher probabilities of being employed at any time. The net inflows into employment indicate better long-term labor market prospects for men.

Finally, we found large discrepancy between the job market experiences of individuals living in rural and urban regions in favor of the former. This difference is surprising since the urban regions are more economically developed. As we have repeatedly indicated, most of the results concerning urban-rural differences have likely been affected by the emergence of the agricultural sector. In the next section, we study the effect of this process by employing models where agricultural and non-agricultural sectors constitute different states.

\section{The role of agriculture in the labor market transformation}

Study of the labor force participation showed a large discrepancy in employment probabilities across rural/urban location. Consistently, individuals living in rural areas appeared to have better labor market experiences. This situation may be, at least in part, due to the emergence of the agricultural sector. The size and the dynamics of this sector, the qualitative difference between the agricultural employment and the employment in the non-agricultural sector, as well as its incidence heavily weighted towards individuals living in rural areas are as many reasons for an in depth study of the role of agriculture in the labor reallocation process.

In this section, we address three groups of questions:

1. Is employment in agriculture a different type of employment?

- We are mainly intersted in comparing the effect of personal characteristics on sector choice (agriculture vs. non-agriculture).

2. Is the emergence of agricultural sector an important determinant of the evolution of the labor market?

- How does the use of a three-state sector changes the effect of personal characteristics on employment probabilities? 


\section{William Davidson Institute Working Paper 481}

- Does agriculture account for the differences in employment probabilities across urban/rural location?

- Does agriculture provide and explanation for the different dynamic of employment probabilities across rural/urban location, level of education, type of skills, and age?

3. Finally, we need to characterize the reallocation processes involving the agricultural sector.

- Who are the individuals more likely to enter the agricultural sector?

- What is the role of the agricultural sector? Is it a transitory state playing a role similar to unemployment or is it an absorbing state?

\subsection{Empirical specification}

We employ a three-state random utility model, where we distinguish between employment in the agricultural and non-agricultural sector. Every time period, individuals choose among three alternative states: employed in the nonagricultural sector, employed in the agricultural sector, and not employed. Each state is associate with a latent variable which can be thought of as the utility of being in the respective state. Every time period, individuals draw realizations of the three latent variables from a known joint distribution. Upon comparing the values of the latent variables, individuals choose the state for the current period.

Let the three latent variables be $U_{i t}^{n a g}, U_{i t}^{a g}$, and $U_{i t}^{n w}$, corresponding to the three states - employed in the non-agricultural sector, employed in the agricultural sector, and not employed, respectively.

$$
\begin{aligned}
U_{i t}^{n a g} & =X_{i} \beta_{t}^{n a g}+u_{i t}^{n a g} \\
U_{i t}^{a g} & =X_{i} \beta_{t}^{a g}+u_{i t}^{a g} \\
U_{i t}^{n w} & =X_{i} \beta_{t}^{n w}+u_{i t}^{n w}
\end{aligned}
$$

$u_{i t}^{n a g}, u_{i t}^{a g}$, and $u_{i t}^{n w}$ have a joint multivariate normal distribution. The dimension of the distribution is $3 T$. Let $u_{i t}=\left[u_{i t}^{n a g}\left|u_{i t}^{a g}\right| u_{i t}^{n w}\right] . E\left[u_{i t}\right]=0, u_{i t}$ are independent over $i$ 's and it has a correlation structure over $t$ given by a general $3 T \times 3 T$ correlation matrix. The number of free elements in the correlation matrix is

$$
3 T(3 T-1) / 2
$$

The state choice is represented by a set of binary variables defined in the following way:

$$
\begin{aligned}
Y_{i t}^{n a g} & =1 \text { if } U_{i t}^{n a g}>U_{i t}^{a g} \text { and } U_{i t}^{n a g}>U_{i t}^{n w} \\
Y_{i t}^{a g} & =1 \text { if } U_{i t}^{a g}>U_{i t}^{n a g} \text { and } U_{i t}^{a g}>U_{i t}^{n w} \\
Y_{i t}^{n w} & =1 \text { if } U_{i t}^{n w}>U_{i t}^{n a g} \text { and } U_{i t}^{n w}>U_{i t}^{a g}
\end{aligned}
$$


Without loss of generality, we can redefine the binary variables.

$$
\begin{aligned}
Y_{i t}^{n a g} & =1 \text { if } U_{i t}^{n a g}>0, U_{i t}^{a g}<0, \text { and } U_{i t}^{n w}<0 \\
Y_{i t}^{a g} & =1 \text { if } U_{i t}^{a g}>0, U_{i t}^{n a g}<0, \text { and } U_{i t}^{n w}<0 \\
Y_{i t}^{n w} & =1 \text { if } U_{i t}^{n w}>0, U_{i t}^{n a g}<0, \text { and } U_{i t}^{a g}<0
\end{aligned}
$$

The resulting multivariate probit models are estimated using Bayesian Markov chain Monte Carlo methods. The Markov chain Monte Carlo sampling scheme is going to be identical to that used for the estimation of the two-state model. The evaluation of the probabilities under the multivariate normal distribution, however, takes into account the truncation implicit in the definition of the binary dependent variable.

\subsection{Estimation results}

The computational cost of estimating the three state model is very large. To speed up estimation, we randomly selected 3517 observations from the full panel. The results are based on 14000 iterations of the Gibbs sampler after burning the first 1000 values. We assume prior independence for the coefficients and the elements of the correlation matrix. The prior distribution of $\beta$ is multivariate normal with a mean vector of 0 and a variance matrix of 100 times the identity matrix. The prior distribution of the elements of the correlation matrix is multivariate normal with a mean vector of 0 and a variance matrix equal to 0.5 times the identity matrix. The OLS coefficients were used as starting values for $\beta$ and 0 for the elements of the correlation matrix. The algorithm is that described in the previous sections.

Tables 8.1, 8.2, 8.3, 8.4 present the estimation results. Indeed the coefficients in the three tables tell a very compelling story. Personal characteristics affect in very different ways the likelihood of an individual being employed compared to the two-sector model. Location, gender and education have opposite effects on the probability of working in the two sectors. As far as the effect of gender and education is concerned, employment in the agricultural sector resembles more non-employment than employment. The correlation coefficients also reveal several interesting aspects. The decisions display a relatively high degree of dependence over time. The exception in this respect is the decision to work in the agricultural sector. The lower magnitude of the own correlation coefficients indicates that the decision to work in agriculture is qualitatively different from the other decisions. If individuals are forced into this sector by losing their jobs and receiving land, then we can expect the correlation between the decisions over time to be weaker. This interpretation is also supported by the very weak cross correlations between the decision to work in agriculture, on one side, and the decisions to work in the non-agricultural sector and not work, on the other side. The weak negative correlation between the non-agriculture and agriculture variables provide support for several alternative processes: a) individuals with 
low unobserved ability were laid-off first and their receiving land was an independent process; b) individuals that received land were the first to be laid-off; c) a combination of a) and b).

Table 8.1. Moments of the posterior distribution for the coefficients.

Non-agricultural sector

\begin{tabular}{||l|l|l|l|l|l|l||}
\hline \hline Variable & \multicolumn{6}{|c||}{ Non-agricultural sector } \\
\hline & 1993 & \multicolumn{1}{|c|}{1994} & \multicolumn{1}{|c||}{1995} \\
\cline { 2 - 7 } Const. & mean & std. & mean & std. & mean & std. \\
\cline { 2 - 7 } Urban & -2.451 & 0.129 & -1.915 & 0.128 & -1.371 & 0.128 \\
Gender & 0.446 & 0.054 & 0.402 & 0.053 & 0.472 & 0.053 \\
Age & 0.322 & 0.052 & 0.504 & 0.052 & 0.511 & 0.051 \\
Gymnasium & 0.028 & 0.002 & 0.015 & 0.002 & -0.001 & 0.002 \\
Vocational & 0.701 & 0.087 & 0.532 & 0.088 & 0.517 & 0.091 \\
Foreman & 1.697 & 0.095 & 1.327 & 0.095 & 1.317 & 0.097 \\
High school & 1.942 & 0.201 & 1.671 & 0.189 & 1.504 & 0.183 \\
HIPLUS & 1.781 & 0.097 & 1.384 & 0.095 & 1.302 & 0.098 \\
University & 2.316 & 0.181 & 1.768 & 0.183 & 1.765 & 0.179 \\
\hline \hline
\end{tabular}


William Davidson Institute Working Paper 481

Table 8.2. Moments of the posterior distribution for the coefficients.

Agricultural sector

\begin{tabular}{||l|l|l|l|l|l|l||}
\hline \hline Variable & \multicolumn{6}{|c||}{ Agricultural sector } \\
\hline & 1993 & \multicolumn{1}{|c|}{1994} & \multicolumn{1}{l||}{1995} \\
\cline { 2 - 7 } Const. & mean & std. & mean & std. & mean & std. \\
\cline { 2 - 7 } & -0.187 & 0.152 & 0.162 & 0.146 & 0.037 & 0.140 \\
Urban & -1.669 & 0.109 & -1.669 & 0.090 & -1.775 & 0.082 \\
Gender & -0.319 & 0.073 & -0.371 & 0.069 & -0.412 & 0.065 \\
Age & 0.010 & 0.003 & 0.008 & 0.003 & 0.013 & 0.003 \\
Gymnasium & -0.420 & 0.092 & -0.515 & 0.092 & -0.390 & 0.089 \\
Vocational & -1.108 & 0.120 & -0.906 & 0.109 & -0.785 & 0.107 \\
Foreman & -1.985 & 0.528 & -1.694 & 0.420 & -0.784 & 0.246 \\
High school & -1.273 & 0.134 & -1.235 & 0.125 & -0.968 & 0.116 \\
HIPLUS & -1.298 & 0.377 & -1.555 & 0.368 & -2.107 & 0.508 \\
University & -4.183 & 1.520 & -6.478 & 1.549 & -1.652 & 0.280 \\
\hline
\end{tabular}

Table 8.3. Moments of the posterior distribution for the coefficients. Not employed.

\begin{tabular}{||l|l|l|l|l|l|l||}
\hline \hline Variable & \multicolumn{7}{|c||}{ Not Employed } \\
\hline & 1993 & \multicolumn{1}{|c||}{1994} & 1995 & \\
\cline { 2 - 7 } Const. & mean & std. & mean & std. & mean & std. \\
\cline { 2 - 7 } & 1.189 & 0.122 & 0.411 & 0.122 & -0.093 & 0.121 \\
Urban & 0.265 & 0.054 & 0.483 & 0.054 & 0.639 & 0.055 \\
Gender & -0.156 & 0.052 & -0.288 & 0.051 & -0.283 & 0.052 \\
Age & -0.034 & 0.002 & 0.021 & 0.002 & 0.011 & 0.002 \\
Gymnasium & -0.250 & 0.082 & -0.004 & 0.084 & -0.057 & 0.085 \\
Vocational & -0.924 & 0.092 & -0.608 & 0.093 & -0.678 & 0.094 \\
Foreman & -1.121 & 0.199 & -0.828 & 0.191 & -0.982 & 0.198 \\
High school & -0.762 & 0.093 & -0.557 & 0.095 & -0.612 & 0.095 \\
HIPLUS & -1.026 & 0.183 & -0.915 & 0.185 & -0.881 & 0.182 \\
University & -1.560 & 0.151 & -1.290 & 0.143 & -1.263 & 0.140 \\
\hline \hline
\end{tabular}


Table 8.4. Moments of the posterior distribution for correlation coefficients.

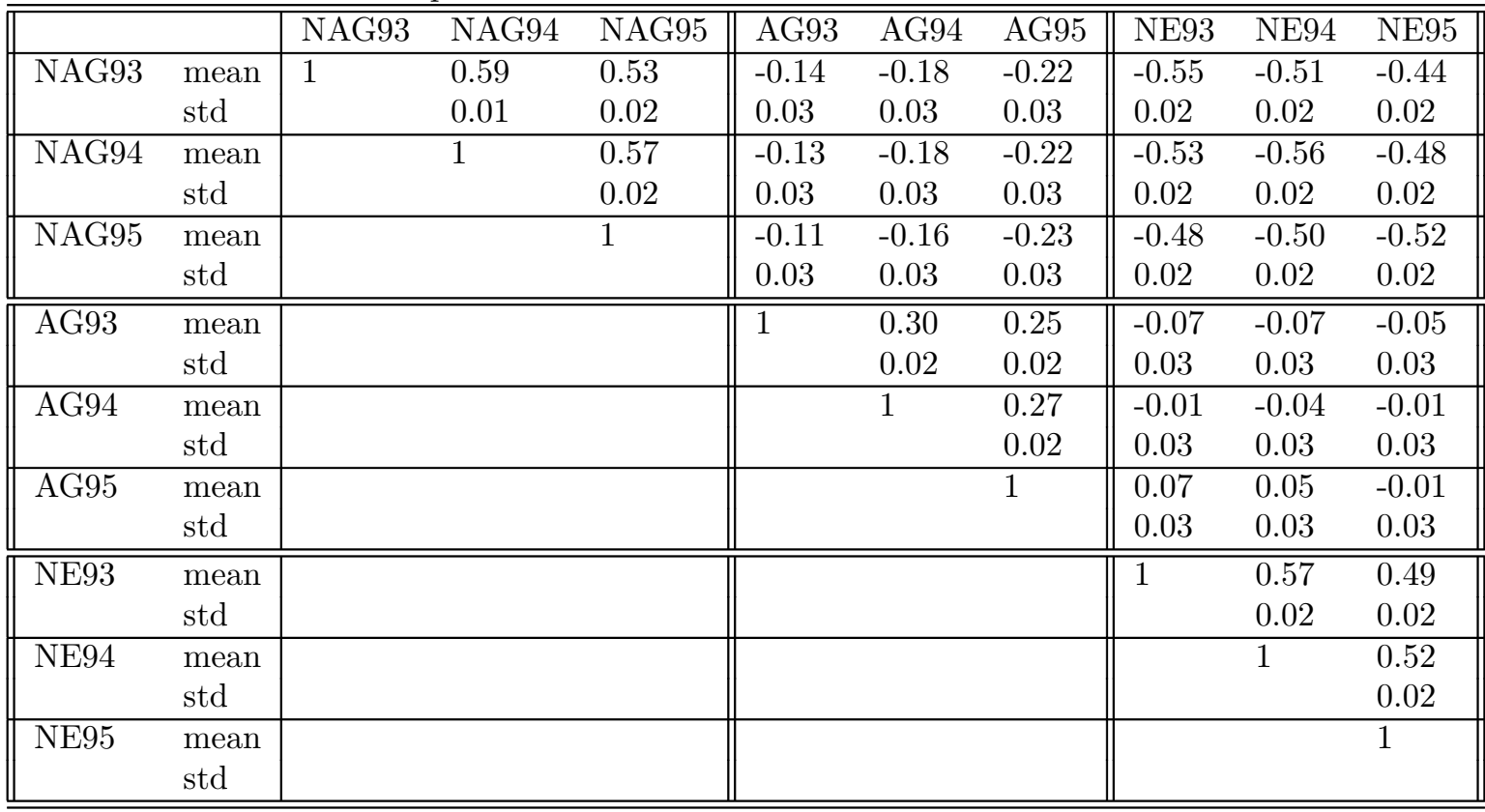

The estimated coefficients provide interesting insights into the questions we have formulated.

- Individuals living in urban areas are more likely to work in the nonagricultural sector or be unemployed and less likely to be employed in the agricultural sector.

- The difference between men and women becomes even sharper. Men are more likely than women to be employed in the non-agricultural sector and less likely to work in agriculture or not being employed. This means that not only are men more likely to be employed but also a larger fraction of those employed will work in the non-agricultural sector

- It is very interesting to consider the dynamics of the effect of age. Initially, older people were more likely to be employed in the non-agricultural sector and in agriculture and less likely to be unemployed. Over time, the effect of age on the probability of working in the non-agricultural sector decreased (became not significant in 1995). By 1995, older people were more likely to be unemployed while the positive effect of age on the probability of being employed in agriculture strengthened.

- Individuals with higher levels of education and high-level of specific skills are more likely to work in the non-agricultural sector and less likely to be unemployed or work in agriculture. The sharp change over time in the coefficients for high-level of specific skills indicate again that many individuals in this category moved to the agricultural sector. 


\subsubsection{Estimated probabilities}

We compute the probabilities of employment in the non-agricultural and agricultural sectors. Tables 9.1 and 9.2 present the results. The probabilities are calculated using the posterior means. To begin with, it is worth noting how the use of the three-state model has changed the estimation results. The coefficients, generally, became sharper. With them, the estimated employment probabilities became more extreme. In the two-state model, we basically constrained the effect of personal characteristics on individuals' decisions to work in the non-agricultural sector and agriculture to be the same. Not surprisingly, as the two decisions turned out to be very different, relaxing this assumption led to the described polarization.

- Indeed, the emergence of the private agricultural sector explains the differences in employment probabilities across locations. Rural residents have higher employment probabilities due to their higher rate of employment in the agricultural sector. For most educational categories, the probability of employment in the non-agricultural sector is smaller than that of people residing in urban areas. Individuals with high level of education are the only exception.

- The increase in employment over time for workers living in rural areas is again due to the emergence of the agricultural sector. The reduction in the probability of working in the non-agricultural sector was more than compensated by the increase in the agricultural employment.

- The effect of specific training is stronger than in the two state model. With the exception of men living in urban areas, the probability of employment in the non-agricultural sector decreased for all individuals in these educational categories. The decline is very sharp for women living in rural areas. For rural areas, the emergence of the agricultural sector and the inflows into this sector overweighted the loss in employment in the non-agricultural sector.

- Finally, it is interesting to mention that, compared with the individuals with specific skills, those with general training maintained a relatively stable probability of working in the non-agricultural sector. 
William Davidson Institute Working Paper 481

Table 9.1. Employment probabilities for the non-agricultural sector.

\begin{tabular}{||l|l|l|l|l||}
\hline \hline Category & & 1993 & 1994 & 1995 \\
Mrban & Primary & 0.315 & 0.353 & 0.359 \\
& Gymnasium & 0.616 & 0.610 & 0.617 \\
& Vocational & 0.948 & 0.934 & 0.938 \\
& Foreman & 0.972 & 0.967 & 0.965 \\
& High school & 0.923 & 0.923 & 0.924 \\
& HIPLUS & 0.966 & 0.976 & 0.975 \\
& University & 0.992 & 0.992 & 0.991 \\
\hline Urban & Primary & 0.148 & 0.146 & 0.148 \\
Female & Gymnasium & 0.388 & 0.339 & 0.341 \\
& Vocational & 0.869 & 0.809 & 0.816 \\
& Foreman & 0.940 & 0.910 & 0.903 \\
& High school & 0.818 & 0.786 & 0.781 \\
& HIPLUS & 0.924 & 0.922 & 0.920 \\
& University & 0.982 & 0.971 & 0.967 \\
\hline Rural & Primary & 0.147 & 0.178 & 0.176 \\
& Gymnasium & 0.485 & 0.498 & 0.484 \\
& Vocational & 0.917 & 0.887 & 0.874 \\
& Foreman & 0.967 & 0.964 & 0.914 \\
& High school & 0.902 & 0.911 & 0.891 \\
& HIPLUS & 0.951 & 0.972 & 0.979 \\
& University & 0.992 & 0.994 & 0.985 \\
\hline \hline \multirow{8}{*}{ Fural } & Primary & 0.058 & 0.055 & 0.053 \\
& Gymnasium & 0.259 & 0.222 & 0.205 \\
& Vocational & 0.806 & 0.707 & 0.672 \\
& Foreman & 0.921 & 0.884 & 0.762 \\
& High school & 0.777 & 0.743 & 0.697 \\
& HIPLUS & 0.902 & 0.910 & 0.929 \\
& University & 0.985 & 0.983 & 0.955 \\
\hline \multirow{8}{*}{ Male } & & & &
\end{tabular}


Table 9.2. Estimated probabilities for the agricultural sector.

\begin{tabular}{||l|l|l|l|l||}
\hline \hline Category & & 1993 & 1994 & 1995 \\
Male & Primary & 0.0131 & 0.0219 & 0.0211 \\
& Gymnasium & 0.0038 & 0.0046 & 0.0062 \\
& Vocational & 0.0002 & 0.0131 & 0.0014 \\
& Foreman & $9 \mathrm{E}-06$ & $5 \mathrm{E}-05$ & 0.0012 \\
& High school & 0.0002 & 0.0003 & 0.0008 \\
& HIPLUS & 0.0001 & $8 \mathrm{E}-05$ & $1 \mathrm{E}-05$ \\
& University & $2 \mathrm{E}-10$ & $5 \mathrm{E}-14$ & $4 \mathrm{E}-05$ \\
\hline Urban & Primary & 0.0216 & 0.0369 & 0.0391 \\
Female & Gymnasium & 0.0091 & 0.0118 & 0.0173 \\
& Vocational & 0.0008 & 0.0042 & 0.0059 \\
& Foreman & $4 \mathrm{E}-05$ & 0.0003 & 0.0062 \\
& High school & 0.0006 & 0.0017 & 0.0044 \\
& HIPLUS & 0.0004 & 0.0005 & $9 \mathrm{E}-05$ \\
& University & $2 \mathrm{E}-09$ & $9 \mathrm{E}-13$ & 0.0003 \\
\hline Rural & Primary & 0.4713 & 0.5887 & 0.6388 \\
Male & Gymnasium & 0.2010 & 0.2375 & 0.3102 \\
& Vocational & 0.0238 & 0.0581 & 0.0869 \\
& Foreman & 0.0029 & 0.0094 & 0.0709 \\
& High school & 0.0196 & 0.0303 & 0.0622 \\
& HIPLUS & 0.0133 & 0.0093 & 0.0038 \\
& University & $2 \mathrm{E}-06$ & $4 \mathrm{E}-09$ & 0.0092 \\
\hline \hline \multirow{5}{*}{ Female } & Primary & 0.6481 & 0.7620 & 0.8003 \\
& Gymnasium & 0.3865 & 0.4473 & 0.5572 \\
& Vocational & 0.0795 & 0.1766 & 0.2485 \\
& Foreman & 0.0129 & 0.0422 & 0.2010 \\
& High school & 0.0620 & 0.1113 & 0.1940 \\
& HIPLUS & 0.0351 & 0.0360 & 0.0188 \\
& University & $8 \mathrm{E}-06$ & $3 \mathrm{E}-08$ & 0.0295 \\
\hline \multirow{5}{*}{ Rural } & & &
\end{tabular}

\subsubsection{Transition probabilities}

The employment probabilities confirmed that agriculture plays an important role in labor force reallocation. Almost all categories of rural residents experienced a rise in the probability of working in the agricultural sector at the expense of the non-agricultural sector and non-employment, which indicates the existence important inflows into the agricultural sector. The estimated transition probabilities describe the composition of the inflows into agriculture. They also allow us to answer an important question about the role of agriculture: is this sector a transitory state, playing the same role as unemployment, or is it an absorbing state?

We begin by analyzing the inflows into the agricultural sector. As the probability of transition into the agricultural sector for urban residents was extremely small, we confine out attention to individuals living in rural areas. Table 10 con- 
tains the estimated transition probabilities.

Table 10. Transitions to the agricultural sector. Rural area

\begin{tabular}{||l|c|l|l|l||}
\hline \hline Origin & \multicolumn{2}{|c|}{ Non-agriculture } & \multicolumn{2}{l||}{ Non-employment } \\
\hline Category & $93-94$ & $94-95$ & $93-94$ & $94-95$ \\
\hline Male & & & & \\
\hline Primary & 0.0356 & 0.0542 & 0.1639 & 0.1030 \\
Gymnasium & 0.0491 & 0.0731 & 0.0676 & 0.0836 \\
Vocational & 0.0360 & 0.0464 & 0.0108 & 0.0144 \\
Foreman & 0.0067 & 0.0556 & 0.0019 & 0.0105 \\
High school & 0.0162 & 0.0360 & 0.0082 & 0.0135 \\
HIPLUS & 0.0057 & 0.0026 & 0.0019 & 0.0005 \\
University & $3 \mathrm{E}-09$ & 0.0086 & $1 \mathrm{E}-09$ & 0.0006 \\
\hline Female & & & & \\
\hline Primary & 0.0295 & 0.0299 & 0.1513 & 0.0965 \\
Gymnasium & 0.0658 & 0.0650 & 0.0967 & 0.1410 \\
Vocational & 0.0926 & 0.0894 & 0.0307 & 0.0480 \\
Foreman & 0.0290 & 0.1333 & 0.0080 & 0.0378 \\
High school & 0.0507 & 0.0790 & 0.0282 & 0.0475 \\
HIPLUS & 0.0192 & 0.0090 & 0.0069 & 0.0034 \\
University & $2 \mathrm{E}-08$ & 0.0260 & $7 \mathrm{E}-09$ & 0.0035 \\
\hline \hline
\end{tabular}

For workers with low level of education, the source of the increase in agricultural employment is the non-employment state. Most of the workers in this category were probably reclassified as employed in the agricultural sector, after receiving land. Among workers with specific training, those who lost their jobs in the restructuring industrial firms made up most of the increase in the agricultural employment. It is also interesting to note the timing of the transition for individuals that arguably posses the highest level of specific training (foreman). Initially, they had a very small probability of moving to the agricultural sector. As the transition progressed they started experiencing larger losses in probability than the other categories.

Next, we compare the nature of agricultural sector and the non-employment state as destinations of outflows from the non-agricultural sector. Table 11 presents the estimated probabilities of moving from the non-agricultural to agriculture and non-employment. Again, we omit urban residents who have very low probabilities of moving to the agricultural sector. Clearly, for individuals living in rural areas, the agricultural sector was the more important destination. Over time, the probability of moving to agriculture increased for all but one categories. It is interesting to note the effect of education:

- People with low level of education will predominantly move to the agricultural sector.

- Initially (1993-1994), men with specific training moved to non-employment. In the second transition (1994-1995), however, the agricultural sector became the more important destination. 
- For women with specific training, the agricultural sector was form the very beginning the more important destination. The flows into agriculture intensified in the second transition.

Table 11. Transitions into and out of non-agricultural sector

\begin{tabular}{||l|l|l|l|l|l|l|l|l||}
\hline \hline Destination & \multicolumn{2}{|l|}{ NAG- NE } & \multicolumn{2}{|c|}{ NAG- $>$ AG } & \multicolumn{2}{l|}{ NE- $>$ NAG } & \multicolumn{2}{l||}{ AG- $>$ NAG } \\
\hline Category & $93-94$ & $94-95$ & $93-94$ & $94-95$ & $93-94$ & $94-95$ & $93-94$ & $94-95$ \\
\hline Male & & & & & & & & \\
Primary & 0.005 & 0.008 & 0.036 & 0.054 & 0.010 & 0.023 & 0.047 & 0.050 \\
Gymnasium & 0.025 & 0.023 & 0.049 & 0.073 & 0.031 & 0.039 & 0.048 & 0.049 \\
Vocational & 0.019 & 0.011 & 0.036 & 0.046 & 0.016 & 0.015 & 0.010 & 0.027 \\
Foreman & 0.010 & 0.007 & 0.007 & 0.056 & 0.008 & 0.013 & 0.002 & 0.004 \\
Highschool & 0.015 & 0.015 & 0.016 & 0.036 & 0.017 & 0.029 & 0.011 & 0.014 \\
HIPLUS & 0.006 & 0.007 & 0.006 & 0.003 & 0.009 & 0.021 & 0.011 & 0.008 \\
University & 0.003 & 0.004 & $3 \mathrm{E}-09$ & 0.009 & 0.003 & 0.005 & $1 \mathrm{E}-06$ & $1 \mathrm{E}-09$ \\
Female & & & & & & & & \\
Primary & 0.003 & 0.003 & 0.029 & 0.030 & 0.003 & 0.006 & 0.024 & 0.028 \\
Gymnasium & 0.026 & 0.014 & 0.066 & 0.065 & 0.018 & 0.017 & 0.039 & 0.044 \\
Vocational & 0.035 & 0.018 & 0.093 & 0.089 & 0.021 & 0.013 & 0.016 & 0.050 \\
Foreman & 0.028 & 0.013 & 0.029 & 0.133 & 0.014 & 0.015 & 0.005 & 0.011 \\
Highschool & 0.030 & 0.021 & 0.050 & 0.079 & 0.023 & 0.027 & 0.020 & 0.032 \\
HIPLUS & 0.015 & 0.016 & 0.019 & 0.009 & 0.020 & 0.020 & 0.022 & 0.024 \\
University & 0.008 & 0.008 & $2 \mathrm{E}-08$ & 0.026 & 0.006 & 0.006 & $7 \mathrm{E}-06$ & $1 \mathrm{E}-08$ \\
\hline \hline
\end{tabular}

Finally, to understand whether the agricultural sector plays the same role as the unemployment, we compare the flows in and out of the non-agricultural sector presented in tables 11 . The results show that the role of agriculture is different across educational categories. Over time, for most categories of education, flows from the non-agricultural sector to agriculture became stronger, while the probability of a reverse transition declined. So, in general, agriculture is becoming an absorbing state.

- For low educated people living in rural areas, employment in agriculture plays the same role as non-employment. The flows between the nonagricultural sector and agriculture are balanced, and are, in both directions, more important than those between the non-agricultural sector and non-employment.

- Individuals with specific training move out of employment in the industrial firms into both non-employment and agriculture. Those that enter the agricultural sector, however, have a lower chance of returning to a job in the non-agricultural sector. Thus, we can consider agriculture as an absorbing state for individuals in this category.

- For rural residents with high education, like urban residents, the agricultural sector is not an important factor. 
The results provide compelling evidence that the creation of the private agricultural sector, is, in a significant measure, responsible for the relatively better labor market performance of rural residents. Agriculture provides both a destination state for non-employed individuals reclassified as employed in agriculture and a transition state for individuals between jobs in the non-agricultural sector.

\section{Conclusions}

In this paper we investigate the effect of the restructuring process on the Romanian labor market. The data were collected at the beginning of the transition process. Despite of the slow pace of the restructuring process in its initial phase, there were strong indications of important labor reallocation processes. The main goal of this paper was to provide a detailed analysis of the labor reallocation mechanisms. Our approach is to study the individual labor market histories. We were primarily interested in estimating the effects of personal characteristics on individuals' labor market experiences during the transition process.

We used several alternative models to describe the process driving individual labor market behavior. We started by employing a two-state model to study labor force participation. As the results indicated that the emergence of the agricultural sector could have had a potentially important effect on the labor market transformation, we continued the analysis using a three-state model of individuals labor market histories. The random utility model used models distinguished between employment in the agricultural and non-agricultural sectors.

All the theoretical models used to describe individual labor market histories had the same statistical representation - the multivariate probit model. The estimation was performed using MCMC methods. The model and the estimation model bring a substantial improvement over existing studies. The model allows for time variant coefficients, a departure from the stationary transition probability matrix typically assumed. Secondly, the estimation method requires no simplifying parametrization of the correlation matrix.

We found a significant labor reallocation process taking place in the Romanian economy. The process was driven by the decline of the industrial sector, the rise in sector like trade, utilities and services, and the emergence of the agricultural sector. Our main interest was to determine the role of the agricultural sector. This was important as employment in the agricultural sector is of much lower quality. We found that rural residents, women and individuals with low levels of education have higher probabilities of working in agriculture. Moreover, we showed that this sector plays a very important role for rural residents. Agriculture became an important destination for individuals who were previously not employed. As we explained, this process was mainly due to the institutional settings associated with the land reform legislation. We found that for low educated people living in rural areas, agricultural employment plays a role similar to the one of unemployment for urban residents. Upon losing their jobs in the non-agricultural sector, most individuals in this category move to agriculture. 
High probabilities of returning to the jobs in the non-agricultural sector indicate that, for many of them, employment in agriculture is only a transitory state. Workers with specific training use both agriculture and unemployment as destinations of their transitions from the non-agricultural sector. For them, however, agriculture is an absorbing state, as the probability of returning to industrial jobs is very small.

In general, individual characteristics like education, age, gender, and location are very important determinants of one's labor market performance, in the midst of the labor reallocation process. The results are consistent with human capital models. Better-educated individuals have the better overall labor-market prospects. This finding is not different from the results of other studies in the literature. It is interesting to note that individuals with a high level of firmand industry-specific skills (vocational, foreman) have a lower probability of losing their jobs. If unemployed, however, they have a smaller chance of finding new jobs. In this respect, the results of this paper differ from those of previous studies. Individuals with no specific skills (high school) have, by far, the highest probability of changing labor force states. The findings regarding the effect of specific skills, are consistent with those formulated by Earle and Pauna (1998) and Earle (1997). The importance of high education is underscored by the fact that, regardless of gender and rural/urban location, individuals with a university degree have the highest employment probability, most of them holding jobs in the non-agricultural sector, and the probability of employment has remained constant over time.

Unlike other studies, we found a significant gap between the labor market prospects of men and women in favor of men. Regardless of location and level of education, men have higher probabilities of being employed at any time. If employed, they have a lower probability of losing their jobs. Men are more likely to hold jobs in the higher quality non-agricultural sector.

Age has an interesting effect on individual labor market histories. Initially, older people were more likely to be employed in the non-agricultural sector and in agriculture and less likely to be unemployed. Over time, the effect of age on the probability of working in the non-agricultural sector decreased indicating that the performance of young people improved. By 1995, older people were more likely to be unemployed while the positive effect of age on the probability of being employed in agriculture strengthened.

From a policy point of view the findings are interesting in several respects. The widening gap between men an women suggests that active labor market policies are necessary to improve women's participation. High education proved to be an important determinant of good labor market performance. General education provides individuals with high mobility and improves their ability to relocate to new growing sectors. The relatively small proportion of population in these educational categories may explain the overall poor performance of the Romanian economy. Policies designed to improve access to higher education, as well as an increase in the importance given to general training are necessary to improve individuals' labor market performance and the performance of the overall economy. 


\section{William Davidson Institute Working Paper 481}

The high proportion of workers with specific training lead to the belief that the work force is well qualified and this would insure a smooth transition process. We found evidence that high specialization reduces workers mobility. Since transition involves reallocation of labor across sectors, highly specialized workers will have a hard time finding new jobs in the newly emerging sectors. This study adds to the growing concern that, the large proportion of workers with specifying training and their strong ties with the shrinking industrial sector will rather have a negative effect on the speed of economic restructuring. Retraining programs are necessary to help workers find jobs in different sectors. Also a shift of focus in vocational education from heavy industry to the growing sectors is necessary. 


\section{Appendix A. Transition matrices}

Table A.1. Transition matrix 1993-1994

\begin{tabular}{|c|c|c|c|c|c|c|c|}
\hline \multirow[b]{2}{*}{$\begin{array}{l}\text { Count } \\
\text { Row percent } \\
\text { Col. percent } \\
\text { Tatal percent }\end{array}$} & \multicolumn{7}{|c|}{ Labor Force Status 1994} \\
\hline & \begin{tabular}{|l|} 
Employed \\
state sector
\end{tabular} & \begin{tabular}{|l} 
Employed \\
private \\
agr. sector
\end{tabular} & \begin{tabular}{|l} 
Employed \\
private \\
non-agr.sector
\end{tabular} & \begin{tabular}{|l|} 
Employed \\
other
\end{tabular} & Unemployed & NLF & Total \\
\hline $\begin{array}{l}\text { Labor Force Status } 1993 \\
\text { Employed } \\
\text { state sector }\end{array}$ & $\begin{array}{r}9242 \\
88.80 \\
93.40 \\
40.50 \\
\end{array}$ & $\begin{array}{r}241 \\
2.30 \\
5.90 \\
1.10 \\
\end{array}$ & $\begin{array}{r}191 \\
1.80 \\
14.00 \\
0.80 \\
\end{array}$ & $\begin{array}{r}46 \\
0.40 \\
9.20 \\
0.20 \\
\end{array}$ & $\begin{array}{r}337 \\
3.20 \\
22.20 \\
1.50 \\
\end{array}$ & $\begin{array}{r}355 \\
3.40 \\
6.50 \\
1.60 \\
\end{array}$ & $\begin{array}{r}10412 \\
46\end{array}$ \\
\hline $\begin{array}{l}\text { Employed private } \\
\text { agricultural sector }\end{array}$ & $\begin{array}{r}63 \\
1.90 \\
0.60 \\
0.30 \\
\end{array}$ & $\begin{array}{r}3134 \\
92.80 \\
77.00 \\
13.70 \\
\end{array}$ & \begin{tabular}{r|}
$\mathbf{2 1}$ \\
0.60 \\
1.50 \\
0.10 \\
\end{tabular} & $\begin{array}{r}9 \\
0.30 \\
1.80 \\
0.00 \\
\end{array}$ & $\begin{array}{r}\mathbf{3 2} \\
0.90 \\
2.10 \\
0.10 \\
\end{array}$ & $\begin{array}{r}118 \\
3.50 \\
2.10 \\
0.50 \\
\end{array}$ & $\begin{array}{r}3377 \\
15\end{array}$ \\
\hline $\begin{array}{l}\text { Employed private } \\
\text { non-agricultural sector }\end{array}$ & $\begin{array}{r}56 \\
5.20 \\
0.60 \\
0.20 \\
\end{array}$ & $\begin{array}{r}\mathbf{1 8} \\
1.70 \\
0.40 \\
0.10 \\
\end{array}$ & $\begin{array}{r}891 \\
82.20 \\
65.10 \\
3.90 \\
\end{array}$ & $\begin{array}{r}11 \\
1.00 \\
2.20 \\
0.00 \\
\end{array}$ & $\begin{array}{r}69 \\
6.40 \\
4.60 \\
0.30 \\
\end{array}$ & $\begin{array}{r}39 \\
3.60 \\
0.70 \\
0.20 \\
\end{array}$ & $\begin{array}{r}1084 \\
5\end{array}$ \\
\hline Employed other & $\begin{array}{r}33 \\
5.80 \\
0.30 \\
0.10 \\
\end{array}$ & $\begin{array}{r}31 \\
5.40 \\
0.80 \\
0.10 \\
\end{array}$ & $\begin{array}{r}26 \\
4.50 \\
1.90 \\
0.10 \\
\end{array}$ & $\begin{array}{r}404 \\
70.60 \\
81.10 \\
1.80 \\
\end{array}$ & $\begin{array}{r}40 \\
7.00 \\
2.60 \\
0.20 \\
\end{array}$ & $\begin{array}{r}38 \\
6.60 \\
0.70 \\
0.20 \\
\end{array}$ & $\begin{array}{r}572 \\
3\end{array}$ \\
\hline Unemployed & $\begin{array}{r}177 \\
9.80 \\
1.80 \\
0.80 \\
\end{array}$ & $\begin{array}{r}203 \\
11.30 \\
5.00 \\
0.90 \\
\end{array}$ & $\begin{array}{r}128 \\
7.10 \\
9.40 \\
0.60 \\
\end{array}$ & $\begin{array}{r}11 \\
0.60 \\
2.20 \\
0.00 \\
\end{array}$ & $\begin{array}{r}766 \\
42.60 \\
50.50 \\
3.40 \\
\end{array}$ & $\begin{array}{r}513 \\
28.50 \\
9.30 \\
2.20 \\
\end{array}$ & $\begin{array}{r}1798 \\
8\end{array}$ \\
\hline NLF & \begin{tabular}{r|}
321 \\
5.70 \\
3.20 \\
1.40 \\
\end{tabular} & $\begin{array}{r}441 \\
7.90 \\
10.80 \\
1.90 \\
\end{array}$ & $\begin{array}{l}111 \\
2.00 \\
8.10 \\
0.50 \\
\end{array}$ & $\begin{array}{r}17 \\
0.30 \\
3.40 \\
0.10 \\
\end{array}$ & $\begin{array}{r}272 \\
4.90 \\
17.90 \\
1.20 \\
\end{array}$ & $\begin{array}{r}4430 \\
79.20 \\
80.60 \\
19.40 \\
\end{array}$ & $\begin{array}{r}5592 \\
25\end{array}$ \\
\hline Total & $\begin{array}{r}9892 \\
43.30 \\
\end{array}$ & $\begin{array}{r}4068 \\
17.80 \\
\end{array}$ & $\begin{array}{r}1368 \\
6.00 \\
\end{array}$ & $\begin{array}{r}498 \\
2.20 \\
\end{array}$ & $\begin{array}{r}1516 \\
6.60 \\
\end{array}$ & $\begin{array}{r}5493 \\
24.10 \\
\end{array}$ & $\begin{array}{r}22835 \\
100 \\
\end{array}$ \\
\hline
\end{tabular}


William Davidson Institute Working Paper 481

Table A.2. Transition matrix 1994-1995

\begin{tabular}{|c|c|c|c|c|c|c|c|}
\hline \multirow[b]{2}{*}{$\begin{array}{l}\text { Count } \\
\text { Row percent } \\
\text { Col. percent } \\
\text { Tatal percent }\end{array}$} & \multicolumn{7}{|c|}{ Labor Force Status 1995} \\
\hline & $\begin{array}{l}\text { Employed } \\
\text { state sector }\end{array}$ & \begin{tabular}{|l} 
Employed \\
private \\
agr. sector
\end{tabular} & \begin{tabular}{|l|} 
Employed \\
private \\
non-agr.sector \\
\end{tabular} & $\begin{array}{l}\text { Employed } \\
\text { other }\end{array}$ & Unemployed & NLF & Total \\
\hline $\begin{array}{l}\text { Labor Force Status } 1994 \\
\text { Employed } \\
\text { state sector }\end{array}$ & $\begin{array}{r}\mathbf{8 2 0 5} \\
82.95 \\
88.23 \\
35.93 \\
\end{array}$ & $\begin{array}{r}364 \\
3.68 \\
7.87 \\
1.59 \\
\end{array}$ & $\begin{array}{r}357 \\
3.61 \\
19.43 \\
1.56 \\
\end{array}$ & $\begin{array}{r}271 \\
2.74 \\
47.96 \\
1.19 \\
\end{array}$ & $\begin{array}{r}306 \\
3.09 \\
20.69 \\
1.34 \\
\end{array}$ & $\begin{array}{r}389 \\
3.93 \\
7.73 \\
1.70 \\
\end{array}$ & $\begin{array}{r}\mathbf{9 8 9 2} \\
43.32 \\
43.32 \\
\end{array}$ \\
\hline $\begin{array}{l}\text { Employed private } \\
\text { agricultural sector }\end{array}$ & $\begin{array}{r}\mathbf{2 1 7} \\
5.33 \\
2.33 \\
0.95 \\
\end{array}$ & $\begin{array}{r}3263 \\
80.21 \\
70.57 \\
14.29 \\
\end{array}$ & $\begin{array}{r}97 \\
2.38 \\
5.28 \\
0.42 \\
\end{array}$ & $\begin{array}{r}\mathbf{2 1} \\
0.52 \\
3.72 \\
0.09 \\
\end{array}$ & $\begin{array}{r}\mathbf{8 1} \\
1.99 \\
5.48 \\
0.35 \\
\end{array}$ & $\begin{array}{r}389 \\
9.56 \\
7.73 \\
1.70 \\
\end{array}$ & $\begin{array}{r}4068 \\
17.81 \\
17.81 \\
\end{array}$ \\
\hline $\begin{array}{l}\text { Employed private } \\
\text { non-agricultural sector }\end{array}$ & $\begin{array}{r}166 \\
12.13 \\
1.78 \\
0.73 \\
\end{array}$ & \begin{tabular}{r|}
62 \\
4.53 \\
1.34 \\
0.27 \\
\end{tabular} & $\begin{array}{r}945 \\
69.08 \\
51.44 \\
4.14 \\
\end{array}$ & $\begin{array}{r}26 \\
1.90 \\
4.60 \\
0.11 \\
\end{array}$ & $\begin{array}{r}74 \\
5.41 \\
5.00 \\
0.32 \\
\end{array}$ & $\begin{array}{r}95 \\
6.94 \\
1.89 \\
0.42 \\
\end{array}$ & $\begin{array}{l}1368 \\
5.99 \\
5.99 \\
\end{array}$ \\
\hline Employed other & $\begin{array}{r}141 \\
28.31 \\
1.52 \\
0.62 \\
\end{array}$ & \begin{tabular}{r|}
24 \\
4.82 \\
0.52 \\
0.11 \\
\end{tabular} & $\begin{array}{r}64 \\
12.85 \\
3.48 \\
0.28 \\
\end{array}$ & $\begin{array}{r}212 \\
42.57 \\
37.52 \\
0.93 \\
\end{array}$ & $\begin{array}{r}30 \\
6.02 \\
2.03 \\
0.13 \\
\end{array}$ & $\begin{array}{r}27 \\
5.42 \\
0.54 \\
0.12 \\
\end{array}$ & $\begin{array}{r}498 \\
2.18 \\
2.18 \\
\end{array}$ \\
\hline Unemployed & \begin{tabular}{r|r}
258 \\
17.02 \\
2.77 \\
1.13 \\
\end{tabular} & $\begin{array}{r}181 \\
11.94 \\
3.91 \\
0.79 \\
\end{array}$ & $\begin{array}{r}193 \\
12.73 \\
10.51 \\
0.85 \\
\end{array}$ & $\begin{array}{r}\mathbf{2 1} \\
1.39 \\
3.72 \\
0.09 \\
\end{array}$ & $\begin{array}{r}\mathbf{5 2 6} \\
34.70 \\
35.56 \\
2.30 \\
\end{array}$ & $\begin{array}{r}337 \\
22.23 \\
6.70 \\
1.48 \\
\end{array}$ & $\begin{array}{l}1516 \\
6.64 \\
6.64 \\
\end{array}$ \\
\hline NLF & $\begin{array}{r}313 \\
5.70 \\
3.37 \\
1.37 \\
\end{array}$ & $\begin{array}{r}730 \\
13.29 \\
15.79 \\
3.20 \\
\end{array}$ & $\begin{array}{r}181 \\
3.30 \\
9.85 \\
0.79 \\
\end{array}$ & $\begin{array}{r}14 \\
0.25 \\
2.48 \\
0.06 \\
\end{array}$ & $\begin{array}{r}\mathbf{4 6 2} \\
8.41 \\
31.24 \\
2.02 \\
\end{array}$ & $\begin{array}{r}3793 \\
69.05 \\
75.41 \\
16.61\end{array}$ & $\begin{array}{r}\mathbf{5 4 9 3} \\
24.06 \\
24.06 \\
\end{array}$ \\
\hline Total & $\begin{array}{r}9300 \\
40.73 \\
\end{array}$ & $\begin{array}{r}4624 \\
20.25\end{array}$ & $\begin{array}{r}1837 \\
8.04\end{array}$ & $\begin{array}{r}565 \\
2.47\end{array}$ & $\begin{array}{r}1479 \\
6.48 \\
\end{array}$ & $\begin{array}{r}5030 \\
22.03\end{array}$ & 22835 \\
\hline
\end{tabular}




\section{Appendix B. MCMC algorithm. \\ The goal in Bayesian estimation is constructing the posterior distributions} for the parameters of interest by integrating the joint posterior distribution. When the number of parameters is large or the model is complicated analytical integration is not possible. Numerical integration can be performed by deterministic or simulation-based methods. Markov chain Monte Carlo (MCMC) algorithms are simulation-based integration methods. A sample must be drawn from the multivariate distribution of interest. This is accomplished by constructing a Markov chain which has a equilibrium distribution that is the distribution of interest. The key element of the chain is the transition kernel, a conditional probability density. The most popular MCMC methods are the Gibbs sampler and the Metropolis-Hastings algorithm. The Gibbs sampler uses a transition kernel based on conditional distributions. Full conditional distributions have to be known and available for sampling. The Metropolis-Hastings algorithm is a more flexible algorithm which uses a kernel based on a candidate distribution and an acception/rejection scheme.

In this paper I use a hybrid algorithm proposed by Chib and Greenberg (1998) - the Gibbs sampler with a Metropolis Hastings step. Using the same approach as data augmentation (Tanner and Wong, 1987) the joint posterior distribution is modified by introducing a latent variable $Z$. The new posterior distribution is:

$$
\pi(\beta, \sigma, Z \mid y) \propto \pi(\beta, \sigma) f(Z \mid \beta, \Sigma) \operatorname{pr}(y \mid Z, \beta, \sigma)
$$

where $\beta$ is a vector of coefficients, $\sigma$ is a vector containing the free elements of the correlation matrix.

Conditional on $Z_{i}, \operatorname{pr}\left(y_{i} \mid Z_{i}, \beta, \sigma\right)=I\left(Z_{i} \in B_{i}\right)$ where $B_{i}$ is the inverse mapping of $y_{i t}=I\left(z_{i t}>0\right)$. The posterior distribution becomes

$$
\pi(\beta, \sigma, Z \mid y) \propto \pi(\beta, \sigma) \prod_{i} f\left(Z_{i} \mid \beta, \Sigma\right) I\left(Z_{i} \in B_{i}\right)
$$

where

$$
f\left(Z_{i} \mid \beta, \Sigma\right) \propto|\Sigma|^{-\frac{1}{2}} \exp \left\{-\frac{1}{2}\left(Z_{i}-X_{i} \beta\right)^{\prime} \Sigma^{-1}\left(Z_{i}-X_{i} \beta\right)\right\} I(\sigma \in C)
$$

and $C$ is the set where the elements of the correlation matrix are defined.

Regarding the latent variable as a parameter, we then sample from the conditional distributions:

- Conditional distribution of $Z_{i}$

$\left[Z_{i} \mid y_{i}, \beta, \Sigma\right] \propto \phi_{T}\left(Z_{i} \mid X_{i} \beta, \Sigma\right) \prod_{i}\left\{I\left(z_{i t}>0\right) I\left(y_{i t}=1\right)+I\left(z_{i t} \leq 0\right) I\left(y_{i t}=0\right)\right\}$ 


\section{William Davidson Institute Working Paper 481}

To draw from a truncated normal distribution, I used the method proposed by Geweke (1991), which consists of running a Gibbs sub-chain with T steps within the main Gibbs sampler cycle.

- Conditional Distribution of $\beta$

We assume prior independence between $\beta$ and $\sigma$. The prior distribution of $\beta$ is a $\mathrm{k}$-variate normal distribution $\pi(\beta)=\phi_{k}\left(\beta \mid \beta_{0}, B_{0}^{-1}\right)$. Conditional distribution is

$$
[\beta \mid Z, \Sigma] \sim N_{k}\left(\beta \mid \hat{\beta}, B^{-1}\right)
$$

where $\hat{\beta}=B^{-1}\left(B_{0} \beta_{0}+\sum_{i=1}^{n} X_{i}^{\prime} \Sigma^{-1} Z_{i}\right)$ and $B=B_{0}+\sum_{i=1}^{n} X_{i}^{\prime} \Sigma^{-1} X_{i}$

- Conditional Distribution of $\sigma$

$$
\begin{gathered}
\pi(\sigma \mid Z, \beta) \propto \pi(\sigma) f(Z \mid \beta, \Sigma) \\
f(Z \mid \beta, \Sigma) \propto|\Sigma|^{-\frac{n}{2}} \exp \left\{-\frac{1}{2} \operatorname{tr}\left(Z^{*}-\Delta\right)^{\prime} \Sigma^{-1}\left(Z^{*}-\Delta\right)\right\} I(\sigma \in C) \\
Z^{*}=\left(Z_{1}, \ldots, Z_{n}\right) \text { and } \Delta=\left(X_{1} \beta, \ldots, X_{n} \beta\right) .
\end{gathered}
$$

Prior distribution of $\sigma$ is a normal distribution truncated at $C$.

$$
\pi(\sigma) \propto \phi_{p}\left(\sigma \mid \sigma_{0}, G_{0}^{-1}\right), \sigma \in C
$$

where $p$ is the number of free parameters in the correlation matrix.

To draw from this distribution I use a MH step within the Gibbs sampler. I ran 15000 iterations of the Gibbs sampler and burned the first 2000 values. I assumed prior independence for the coefficients and the elements of the correlation matrix. The prior distribution of $\beta$ is multivariate normal with a mean vector of 0 and a variance matrix of 100 times the identity matrix. The prior distribution of the elements of the correlation matrix is multivariate normal with a mean vector of 0 and a variance matrix equal to 10 times the identity matrix. The OLS coefficients were used as starting values for $\beta$ and 0 for the elements of the correlation matrix. The algorithm is that described in section 3. The proposal density used to generate candidate values in the $\mathrm{MH}$ step is $q\left(\phi \mid \sigma_{i}^{k}\right)=s * g\left(\phi-\sigma_{i}^{k}\right)$ where $g$ is the standard normal distribution and $s$ is the step size. We use a step size $s=1000 / N$. 


\section{References}

Abraham, K. and M. Vodopivec, 1993, "Slovenia: A Study of Labor Market Transitions," mimeo. (The World Bank, Washington, DC).

Amemiya, T., 1985, Advanced Econometrics, Cambridge: Harvard University.

Barr, N., 1994. "Labour Markets and Social Policy in Central and Eastern Europe," New York.

Bellmann, L, S. Estrin, H. Lehmann, and J. Wadsworth, 1995, "The Eastern German Labor Market in Transition: Gross Flow Estimates from Panel Data," Jornal of Comparative Economics, 20, 139-170.

Boeri, T., 1994, "Transitional Unemployment," Economics of Transition, 2, 1-25.

Bound, J. et al., 1990, "Measurement Error in Cross-Sectional and Longitudinal Labor Market Surveys: Validation Study Evidence," Panel data and labor market studies, Hartog, Joop Ridder, Geert Theeuwes, Jules, eds., Contributions to Economic Analysis, vol. 192 Amsterdam; Oxford and Tokyo: North-Holland; distributed in the U.S. and Canada by Elsevier Science, New York, 1-19.

Chib, S., and E. Greenberg (1998), "Analysis of Multivariate Probit Models," Biometrika, 85, 347-361.

Commander, S. and F. Coricelli, 1995. "Unemployment and Restructuring in Eastern Europe and Russia," World Bank, Washington D.C.

Commander, S. and A. Tolstopiatenko, 1997. "Unemployment, Restructuring and the Pace of Transition," Lessons from the Economic Transition. Central and Eastern Europe, OECD.

Earle, J. S., 1997. "Industrial Decline and Labor Reallocation in Romania," SITE working paper.

Earle, J. S. and C. Pauna,1998, "Long-term Unemployment, Social Assistance and Labor Market Policies in Romania," Empirical Economics, 23, 203235 .

Finta, J. and K. Terrel, 1997, "Gender Differences in Flows Across Labor Market States in the Czech Republic," unpublished paper, (University of Michigan, Ann Arbor, MI.

Foley, M. C., 1997, "Determinants of unemployment Duration in Russia," Working paper no. 81 (The William Davidson Institute, University of Michigan Business School, Ann Arbor, MI. 
Geweke, J. (1989), "Bayesian Inference in Econometric Models Using Monte Carlo Integration," Econometrica, 57,1317-1340.

Geweke, J. (1991), "Efficient Simulation from the Multivariate Normal and Student-T Distributions Subject to Linear Constaraints." In Computing Science and Statistics: Proceedings of the 23rd Symposium on the Interface, Ed. E. Keramidas and S. Kaufman, 571-578, Fairfax Station, VA: Interface Foundation of North American.

Geweke, J. (1992), "Evaluating the Accuracy of Sampling-Based Approaches to the Calculation of Posterior Moments," Bayesian Statistics 4, ed. J.M. Bernardo, J.O. Berger, A.P. David, and A.F.M. Smith, 169-193.

Greene, W. H., 1997, Econometric Analyisis, Prentice Hall.

Hajivassiliou, V., 1990, "Smooth Simulation Estimation of Panel Data LDV Models," Department of Economics, Yale University.

Ham, J., J. Svejnar and K. Terrel, 1998, "Unemployment and Social Safety Net During Transitions to a Market Economy:Evidence from the Czech and Slovak Republics," American Economic Review, 88,1117-1142.

Ham, J., J. Svejnar and K. Terrel, 1999, "Women's Unemployment During Transition: Evidence from Czech and Slovak Micro-Data," Economics of Transition, 7, 47-78.

Heckman, J. J., 1993, "What Has Been Learned About Labor Supply in the Past Twenty Years?" American Economic Review, 83, 116-121.

Jones, D. C. and T. Kato, 1997, "The Nature and the Determinants of Labor Mrket Transitions in Former Communist Economies: Evidence from Bulgaria," Industrial Relations, 36, 229-254.

Hyslop, D., 1999, "State Depandence, Serial Correlation and Heterogeneity in Intertemporal Labor Force Participation of Married Women," Econometrica, 67, 1255-1294.

Keane, M., 1994, "A Computationally Practical Simulation Estimator for Panel Data," Econometrica, 62, 95-116.

Micklewright, J. and G. Nagy, 1995, "Unemployment Insurance and Incentives in Hungary," discussion paper no. 1118 (CEPR, London).

Micklewright, J. and G. Nagy, 1997, "The Implications of Exhausting Unemployment Insurance Entitlement in Hungary," occasional papers No. 58 (Economic and Social Policy Series, United nations Children's Fund).

OECD, 1998, OECD Economic Surveys, 1998, Romania. 


\section{William Davidson Institute Working Paper 481}

Storm, V. and K. Terrell, 1997, "Employment, Unemployment in Transition in the Czech Republic: Where Have All the Workers Gone?" mimeo, The William Davidson Institute, University of Michigan Business School, Ann Arbor, MI.

Svejnar, J., 1999, "Labor Markets in the Transitional Central and East European Economies," Handbook of Labor Economics, Volume 3, Elsevier Science.

Tanner, T. A., and Wong, W. H (1987), "The Calculation of Posterior Distributions by Data Augmentation," Journal of the American Statistical Association, 82, 528-549.

Voicu, A. (2001), "Labor Force Participation Dynamics in the Romanian Labor Market. A Bayesian Markov Chain Monte Carlo Approach" Ph.D. Thesis, Rutgers University. 


\section{DAVIDSON INSTITUTE WORKING PAPER SERIES - Most Recent Papers}

The entire Working Paper Series may be downloaded free of charge at: www.wdi.bus.umich.edu

CURRENT AS OF $7 / 10 / 02$

\begin{tabular}{|c|c|c|}
\hline Publication & Authors & Date \\
\hline $\begin{array}{l}\text { No. 481: Labor Force Participation Dynamics in the Romanian Labor } \\
\text { Market }\end{array}$ & Alexandru Voicu & July 2002 \\
\hline $\begin{array}{l}\text { No. 480: Equilibrium Real Exchange Rates in Central Europe's } \\
\text { Transition Economies : Knocking on Heaven's Door }\end{array}$ & Balázs Égert & July 2002 \\
\hline $\begin{array}{l}\text { No. 479: The Impact of Minimum Wages on Wage Inequality and } \\
\text { Employment in the Formal and Informal Sector in Costa Rica }\end{array}$ & $\begin{array}{l}\text { Fatma El-Hamidi and Katherine } \\
\text { Terrell }\end{array}$ & Apr. 2001 \\
\hline $\begin{array}{l}\text { No. 478: Beyond Oaxaca -Blinder: Accounting for Differences in } \\
\text { Household Income Distributions }\end{array}$ & $\begin{array}{l}\text { François Bourguignon, Francisco } \\
\text { H. G. Ferreira and Phillippe G. } \\
\text { Leite }\end{array}$ & Feb. 2002 \\
\hline $\begin{array}{l}\text { No. 477: Participation Behavior of East German Women after German } \\
\text { Unification }\end{array}$ & Holger Bonin and Rob Euwals & July 2002 \\
\hline No. 476: Duration and Risk of Unemployment in Argentina & $\begin{array}{l}\text { Sebastian Galiani and Hugo A. } \\
\text { Hopenhayn }\end{array}$ & Oct. 2001 \\
\hline $\begin{array}{l}\text { No. 475: After, Before and During: Returns to Education in the } \\
\text { Hungarian Transition }\end{array}$ & $\begin{array}{l}\text { Nauro F. Campos and Dean } \\
\text { Jolliffe }\end{array}$ & Apr. 2002 \\
\hline No. 474: The Locking-in Effect of Subsidized Jobs & Jan C. van Ours & June 2002 \\
\hline No. 473: How Reform Worked in China & Yingyi Qian & June 2002 \\
\hline No. 472: An Economic Perspective on Russia's Accession to & Robert M. Stern & June2002 \\
\hline $\begin{array}{l}\text { No. 471: The Effects of Ownership Forms and Concentration on Firm } \\
\text { Performance after Large-Scale Privatization }\end{array}$ & Evzen Kocenda a & May 2002 \\
\hline $\begin{array}{l}\text { No. 470: Growth in Transition: What We Know, What We Don't, and } \\
\text { What We Should }\end{array}$ & $\begin{array}{l}\text { Nauro F. Campo } \\
\text { Coricelli }\end{array}$ & Feb. 2002 \\
\hline $\begin{array}{l}\text { No. 469: Barriers to Investment by Russian Firms: Property Protection } \\
\text { or Credit Constraints? }\end{array}$ & Susan J. Linz & May 2002 \\
\hline No. 468: Job Satisfaction Among Russian Workers & J. Linz & May 2002 \\
\hline $\begin{array}{l}\text { No. 467: Assessing the Problem of Human Capital Mismatch in } \\
\text { Transition Economies }\end{array}$ & $\begin{array}{l}\text { Viliam Druska, Byeong ju Jeong, } \\
\text { Michal Kejak, and Viatcheslav } \\
\text { Vinogradov }\end{array}$ & Mar. 2002 \\
\hline $\begin{array}{l}\text { No. 466: Motivating Russian Workers: Analysis of Age and Gender } \\
\text { Differences }\end{array}$ & Susan J. Linz & Feb. 2002 \\
\hline No. 465: Virtual Reality: Barter and Restructuring in Russian Industry & Gary Krueger and $\mathrm{Su}$ & Apr. 2001 \\
\hline $\begin{array}{l}\text { No. 464: Lending of Last Resort, Moral Hazard and Twin Crises: } \\
\text { Lessons from the Bulgarian Financial Crisis 1996/1997 }\end{array}$ & $\begin{array}{l}\text { Michael Berlemann, Kalin } \\
\text { Hristov and Nikolay Nenovsky }\end{array}$ & May 2002 \\
\hline $\begin{array}{l}\text { No. 463: Deindustrialisation. Lessons from the Structural Outcomes of } \\
\text { Post-Communist Transition }\end{array}$ & $\begin{array}{l}\text { Tomasz Mickiewicz and Anna } \\
\text { Zalewska }\end{array}$ & Jan. 2002 \\
\hline $\begin{array}{l}\text { No. 462: Joint Liability Lending and the Rise and Fall of China's } \\
\text { Township and Village Enterprises }\end{array}$ & Albert Park and Minggao Shen & July 2001 \\
\hline $\begin{array}{l}\text { No. 461: A Refinancing Model of Decentralization with Empirical } \\
\text { Evidence from China }\end{array}$ & Albert Park and Minggao Shen & Apr. 2002 \\
\hline $\begin{array}{l}\text { No. 460: The Effects of Market Liberalization on the Relative Earnings } \\
\text { of Chinese Women }\end{array}$ & $\begin{array}{l}\text { Margaret Maurer-Fazio and } \\
\text { James Hughes }\end{array}$ & Mar. 2002 \\
\hline $\begin{array}{l}\text { No. 459: The Role of Education in Determining Labor Market } \\
\text { Outcomes in Urban China's Transitional Labor Markets }\end{array}$ & Margaret Maurer-Fazio & Apr. 2002 \\
\hline $\begin{array}{l}\text { No. 458: Real and Monetary Convergence within the European Union } \\
\text { and Between the European Union and Candidate Countries: } \\
\text { A Rolling Cointegration Approach }\end{array}$ & $\begin{array}{l}\text { Josef C. Brada, Ali M. Kutan and } \\
\text { Su Zhou }\end{array}$ & Apr. 2002 \\
\hline No. 457: Credit Ratings as Coordination Mechanisms & $\begin{array}{l}\text { Arnoud W. A. Boot and Todd T. } \\
\text { Milbourn }\end{array}$ & Mar. 2002 \\
\hline $\begin{array}{l}\text { No. 456: Balkan and Mediterranean Candidates for European Union } \\
\text { Membership: The Convergence of their Monetary Policy with that of the } \\
\text { European Central Bank }\end{array}$ & Josef C. Brada and Ali M. Kutan & Apr. 2002 \\
\hline
\end{tabular}

